\title{
Discussion Paper No. 13-006 \\ Revealed Preferences for Climate Protection when the Purely Individual Perspective is Relaxed - Evidence from a Framed Field Experiment
}

Andreas Löschel, Bodo Sturm, and Reinhard Uehleke

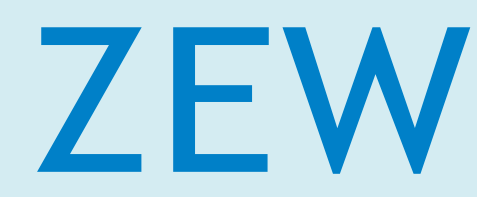

Zentrum für Europäische Wirtschaftsforschung $\mathrm{GmbH}$ Centre for European Economic Research 
Discussion Paper No. 13-006

\title{
Revealed Preferences for Climate Protection when the Purely Individual Perspective is Relaxed - Evidence from a Framed Field Experiment
}

\author{
Andreas Löschel, Bodo Sturm, \\ and Reinhard Uehleke
}

Download this ZEW Discussion Paper from our ftp server:

http://ftp.zew.de/pub/zew-docs/dp/dp13006.pdf

Die Discussion Papers dienen einer möglichst schnellen Verbreitung von neueren Forschungsarbeiten des ZEW. Die Beiträge liegen in alleiniger Verantwortung der Autoren und stellen nicht notwendigerweise die Meinung des ZEW dar.

Discussion Papers are intended to make results of ZEW research promptly available to other economists in order to encourage discussion and suggestions for revisions. The authors are solely responsible for the contents which do not necessarily represent the opinion of the ZEW. 


\section{Non-technical summary}

Since the problem of climate change has drawn attention both in political and academic agenda, the question of how much people are willing to pay for the mitigation of global warming has been a subject of keen enquiry. Several recent studies have addressed the issue of the Willingness-to-Pay (WTP) for climate protection and results have given an almost similar plurality of amounts as there have been studies. This diversity can be explained, among other reasons, by the differences in the design of the corresponding studies. While most authors employed a stated preferences approach - where subjects indicate their WTP hypothetically and without any real payment - leading to a relatively high value of WTP, some studies utilised a revealed preference framework - where real payments have to be done. Comparison of the two different approaches show that the revealed preferences studies result in much lower values for WTP.

Existing revealed preference studies, however, face the following difficulty. The values reported from such studies are obtained in a decision framework wherein individuals face the opportunity to free ride on emissions reductions by others. Subjects may withhold their contribution to the public good climate protection while others contribute. While the WTP obtained in such a framework is certainly of interest, it is conceivable that the corresponding WTP is higher in a decision framework which at least partly excludes the free riding opportunity by introducing some form of collective decision.

In this paper, we study the demand for climate protection when the purely individual perspective of previous revealed preference studies is relaxed. We investigate whether the WTP for climate protection depends (i) on the information of real behaviour of subjects in a similar decision making situation and (ii) on the introduction of collective action.

Participants in our framed field experiment were remunerated with $40 €$ cash for their time in partaking in this investigation and were then given the opportunity to contribute to $\mathrm{CO}_{2}$ emissions reduction by buying European Union Allowances (EUAs). Each participant was confronted with two different prices for permits in $100 \mathrm{~kg} \mathrm{CO}_{2}$. Subjects were then asked to indicate the quantity of permits they would be willing to buy at each of the prices. Finally, one of the two prices was randomly selected by the administrator and the transaction was carried out at the corresponding price. Any allowances purchased were withdrawn from the European Emissions Trading Scheme, therefore it can be stated that all contributions led to real reduction in emissions. In one treatment of the study, we introduced a collective action whereby all members of a group were forced to purchase the median amount of EUAs demanded by the group. In another treatment, subjects received information about the real demand revealed by other subjects in a similar decision making situation. The information on previous contributions may signal the level of contribution by others.

The main finding from our study is that the probability of purchasing EUAs is higher in the treatment with collective action compared to the treatment where no collective decision was implemented. The provision of information about other subjects' behaviour, however, has no treatment effect on the demand for climate protection. The mean (median) WTP amounts to $11 € / \mathrm{tCO}_{2}\left(5 € / \mathrm{tCO}_{2}\right)$ in total. Furthermore, we observe a strong correlation between subjects' demand and their expectations about other participants' behaviour. When collective action is not available, subjects' expectations are consistent with free rider behaviour. 


\section{Das Wichtigste in Kürze}

Die Höhe der Zahlungsbereitschaft für das öffentliche Gut Klimaschutz ist Gegenstand einer Vielzahl von Untersuchungen. Die ermittelten Zahlungsbereitschaften unterscheiden sich dabei zum Teil erheblich, was unter anderem auf Unterschiede im Design der Studien zurückzuführen sein dürfte. Die überwiegende Mehrheit der Studien zur Ermittlung der Zahlungsbereitschaft für Klimaschutz nutzt Befragungen, bei denen die Teilnehmer ihre Zahlungsbereitschaft in einer hypothetischen Entscheidungssituation angeben und keine realen Transaktionen getätigt werden. Nur wenige Studien nutzen die Möglichkeit, die Zahlungsbereitschaft aus einer realen ökonomischen Transaktion abzuleiten. Die ermittelten hypothetischen Zahlungsbereitschaften für Klimaschutz sind zumeist deutlich höher als die realen Zahlungsbereitschaften.

In Studien, die eine reale Zahlungsbereitschaft für Klimaschutz erheben, haben die Teilnehmer jedoch die Möglichkeit freizufahren, d.h. keinen Beitrag zum öffentlichen Gut zu leisten, während andere Teilnehmer in der Gruppe beitragen. Es ist zu vermuten, dass die Zahlungsbereitschaft für Klimaschutz höher ausfällt, wenn es keine Freifahreroption in der Gruppe der Teilnehmer gibt und alle Teilnehmer den gleichen Beitrag leisten müssen.

In dieser Studie betrachten wir die reale Zahlungsbereitschaft nach Klimaschutz, wobei die individuelle Perspektive bisheriger Studien zur realen Zahlungsbereitschaft gelockert wird. Wir untersuchen, ob die Zahlungsbereitschaft von (i) Informationen über das reale Verhalten von Akteuren in einer ähnlichen Entscheidungssituation und (ii) der Einführung einer kollektiven Aktion abhängt. Die Information zu vergangenem Verhalten ermöglicht eine bessere Einschätzung des Beitragsverhaltens anderer Teilnehmer. Durch die kollektive Aktion ist jeder Teilnehmer in der Gruppe verpflichtet, den gleichen Beitrag zum Klimaschutz zu leisten.

Teilnehmer an unserer Studie erhielten eine Aufwandsentschädigung von $40 €$ und konnten durch den Kauf von Zertifikaten des EU-Emissionshandels einen Beitrag zum Klimaschutz leisten. Jeder Teilnehmer konnte dabei für zwei unterschiedliche Preise seine Nachfrage nach Zertifikaten (in $100 \mathrm{~kg} \mathrm{CO}_{2}$ ) angeben. Ein Preis wurde ausgelost und diese Menge wurde zum ausgelosten Preis gekauft. Gekaufte Zertifikate wurden gelöscht, d.h., jeder Beitrag führte zu einer realen Reduzierung der $\mathrm{CO}_{2}$-Emissionen in Europa. Eine Gruppe der Teilnehmer erhielt Informationen über das reale Kaufverhalten von Akteuren in einer ähnlichen Entscheidungssituation. In einer anderen Gruppe mussten alle Teilnehmer die Medianmenge der Gruppe, d.h. die Menge, welche die Hälfte aller Teilnehmer zu einem bestimmten Preis nachgefragt hat, kaufen.

Ergebnis unserer Studie ist, dass mit einer kollektiven Aktion die Wahrscheinlichkeit Zertifikate zu kaufen höher ist als ohne kollektive Aktion. Informationen über das reale Verhalten von Akteuren in einer ähnlichen Entscheidungssituation haben keinen Effekt auf das Beitragsverhalten. Der Durchschnitt der Zahlungsbereitschaft beträgt insgesamt $11 € / \mathrm{tCO}_{2}$, der Median der Zahlungsbereitschaft liegt bei $5 € / t \mathrm{CO}_{2}$. Darüber hinaus ist eine starke positive Korrelation zwischen der individuellen Nachfrage nach Zertifikaten und der Erwartung über die nachgefragte Menge der anderen Teilnehmer zu beobachten. Ohne kollektive Aktion sind die Erwartungen der Teilnehmer konsistent mit Freifahrerverhalten, d.h., die Teilnehmer kaufen weniger Zertifikate als sie es im Durchschnitt von den anderen Teilnehmern erwarten. 


\title{
Revealed Preferences for Climate Protection when the Purely Individual Perspective is Relaxed - Evidence from a Framed Field Experiment
}

\author{
Andreas Löschel $^{\mathrm{a}, \mathrm{b}}$, Bodo Sturm ${ }^{\mathrm{a}, \mathrm{c}}$, and Reinhard Uehleke ${ }^{\mathrm{c}}$ \\ ${ }^{a}$ Centre for European Economic Research (ZEW), Mannheim \\ ${ }^{\mathrm{b}}$ Alfred Weber Institute, University of Heidelberg \\ ${ }^{c}$ Department of Business Administration, Leipzig University of Applied Sciences \\ E-mail: \\ loeschel@zew.de, \\ bodo.sturm@wiwi.htwk-leipzig.de, \\ reinhard.uehleke@wiwi.htwk-leipzig.de
}

January $4^{\text {th }} 2013$

\begin{abstract}
In this paper, we investigate the real demand for climate protection when the purely individual perspective of existing revealed preference studies is relaxed. This is achieved in two treatments; first, we determine the information subjects receive about the demand revealed by other subjects in a similar decision making situation, second, collective action is implemented whereby all subjects are required to purchase the group's median quantity at a given price. Participants in the experiment were offered the opportunity to contribute to climate protection by purchasing European Union Allowances. Allowances purchased were withdrawn from the European Emissions Trading Scheme. In our experiment, information about other subjects' behaviour has no treatment effect on the demand for climate protection. Under collective action however, the probability of purchasing allowances is higher compared to the reference treatment situation, an individual contribution mechanism. Furthermore, we observe a strong correlation between subjects' demand and their expectations about other participants' behaviour. When collective action is not available, subjects' expectations are consistent with free rider behaviour.
\end{abstract}

JEL classification: Q51, Q54, C93

Keywords: Experimental economics, demand for climate protection, climate change, willingness to pay

Acknowledgements: The authors thank Francois Laisney and Carsten Vogt. Support by the Wissenschaftsgemeinschaft Gottfried Wilhelm Leibniz (WGL) and the German Federal Ministry of Education and Research (FKZ 01LA1108B) is gratefully acknowledged. 


\section{Introduction}

Since the problem of climate change has drawn attention both in political and academic agenda, the question of how much people are willing to pay for the mitigation of global warming has been a subject of keen enquiry. Several recent studies have addressed this issue and results have given an almost similar plurality of amounts as there have been studies. Median values for the willingness-to-pay (WTP) for climate protection range from $0 € / \mathrm{tCO}_{2}$ (Löschel et al. 2013, Diederich and Göschel 2011) to 256€/tCO (Achtnicht 2012). This diversity can be explained, among other reasons, by the differences in the design of the corresponding studies. While most authors have employed a stated preferences approach leading to a relatively high value of WTP, a smaller sample of studies has utilised a revealed preference framework. Comparison of the two different approaches show that the revealed preferences studies result in much lower values for WTP. One might argue that the stated preferences approach suffers from what has been called the hypothetical bias in the literature (e.g., Murphy et al. 2005) and, hence, leads to overly optimistic estimates for the WTP.

Similarly however, revealed preference studies face their own difficulties. The values reported from such studies are obtained in a decision framework wherein individuals face the opportunity to free ride on emissions reductions by others. While the WTP obtained in such a framework is certainly of interest, it is conceivable that the corresponding WTP is higher in a decision framework which, at least partly, excludes the free riding opportunity by introducing some form of collective decision. For example, this could apply in the existence of conditional co-operators, i.e. subjects who are only willing to contribute to a public good if they can be sure that others also contribute. Such subjects will be more likely to contribute when they are certain that others do as well.

In this paper, we study the demand for climate protection when the purely individual perspective of previous revealed preference studies is relaxed. We investigate whether the WTP for climate protection depends (i) on the information of real behaviour of subjects in a similar decision making situation and (ii) on the introduction of collective action. The information on previous contributions (or lack thereof) by others may signal the level of current contribution by others and thus also have positive effects on the individual decision to contribute. A collective decision, such as a median rule, where each participant of an experiment is required to purchase the median amount of $\mathrm{CO}_{2}$ emissions reduction, may be a device to ensure those conditional co-operators of the contributions of others. Hence, under a collective decision rule more subjects are expected to contribute to the provision of the public good. 
Participants in our framed field experiment ${ }^{1}$ were remunerated with $40 €$ cash for their time in partaking in this investigation and were then given the opportunity to contribute to $\mathrm{CO}_{2}$ emissions reduction by buying European Union Allowances (EUAs). Any allowances purchased were withdrawn from the European Emissions Trading Scheme (EU ETS), therefore it can be stated that all contributions led to real reduction in emissions. In one treatment of the study, we introduced a collective action whereby all members of a group were forced to purchase the median amount of EUAs demanded by the group. In another treatment, subjects received information about the real demand revealed by other subjects in a similar decision making situation.

The main finding from our study is that the probability of purchasing EUAs is higher in the treatment with collective action compared to the treatment where no collective decision was implemented. The provision of information about other subjects' behaviour, however, has no treatment effect on the demand for climate protection. The mean (median) WTP amounts to $11 € / \mathrm{tCO}_{2}\left(5 € / \mathrm{tCO}_{2}\right)$ in total. This confirms the low values reported in Diederich and Göschl (2011) and Löschel et al. (2013). Furthermore, we observe a strong correlation between subjects' demand and their expectations about other participants' behaviour. When collective action is not available, subjects' expectations are consistent with free rider behaviour.

The paper is organised as follows. In section 2, a brief overview of the literature related to the issue of WTP for $\mathrm{CO}_{2}$ emissions reductions is given. Section 3 describes the design of the experiment while section 4 states the main hypotheses with respect to the expected effects of the treatment variables. Section 5 gives the results and section 6 concludes with a discussion of the results.

\section{Related literature}

At least three branches of literature are directly related to our study. First, are the several stated preferences studies which have recently explored the question of WTP measured in monetary units per $\mathrm{tCO}_{2}$ for the mitigation of climate change. ${ }^{2 \cdot 3}$ MacKerron et al. (2009)

\footnotetext{
1 According to the classification suggested by Harrison and List (2004), a framed field experiment is the same as a conventional lab experiment, but with a nonstandard (i.e. students) subject pool and with field context in either commodity, task, or information set that the subjects can use.

${ }^{2}$ In this paper, all WTP values are, if necessary, converted to $€$ values using the 2010 ECB average reference exchange rate for US\$ ( $€ 1=$ US $\$ 1.3257)$ or GBP $(€ 1=$ GBP 0.8578$)$.

3 Johnson and Nemet (2010) surveyed 27 stated preference studies that estimated WTP as a total amount of money or percentage of income people are willing to give up per unit of time, e.g. within a year, in order to achieve a specific amount of mitigation. They found that the WTP for climate protection ranged between $17 €$ and $330 €$ per household annually, with a mean of $126 €$ and a median of $102 €$. Due to differences in scenarios,
} 
estimated the WTP for voluntary carbon offsets against an aviation-related background. Participants of their study were asked to state the amount they would be willing to pay to offset their $\mathrm{CO}_{2}$ emissions during a hypothetical flight from New York to London. They estimated the mean WTP for the offset to be approximately $28 € / \mathrm{CCO}_{2}$. In a similar study, Brouwer et al. (2007) asked airport passengers for their WTP to reduce $\mathrm{CO}_{2}$ emissions caused by their flights. Accordingly, the mean WTP for the reduction of one $\mathrm{tCO}_{2}$ across all passengers amounted to $25 €$, with a remarkable geographical variation: Mean WTP for Asian travellers was found to be the lowest at a value of $10 € / \mathrm{tCO}_{2}$ while European participants were recorded as willing to pay a mean value of $41 € / \mathrm{tCO}_{2}$. Achtnicht (2012) measured the WTP for the reduction of $\mathrm{CO}_{2}$ using data from interviews with more than 600 potential car-buyers across Germany. The interviewees were presented with a stated preference choice experiment consisting of hypothetical car types that differed in various characteristics such as price, propulsion technologies, fuel type, and $\mathrm{CO}_{2}$ emissions per 100 kilometres. The WTP for the reduction of one $\mathrm{tCO}_{2}$ can be indirectly inferred from the choices revealed in the survey. Achtnicht estimated a median WTP for the reference group which resulted in a range of $89 €$ to $256 € / \mathrm{tCO}_{2}$, significantly higher than the aforementioned estimates. Viscusi and Zeckhauser (2006) analysed the willingness of Harvard graduate students to pay higher petrol taxes in order to help counteract global warming. They identified an average WTP of $0.79 \$$ per gallon of petrol whilst the median WTP was found to be $0.44 \$$ per gallon. Since there is a direct relation between petrol input and $\mathrm{CO}_{2}$ emissions, these values can accurately be converted to $67 € / \mathrm{tCO}_{2}$ (mean) and $38 € / \mathrm{tCO}_{2}$ (median). In a recent paper, Blasch and Farsi (2012) reported on survey data pertaining to the WTP for voluntary carbon offsets in the range of $0.75 € / t \mathrm{CO}_{2}$ to $€ 16.60 € / \mathrm{tCO}_{2}$ depending on the emission activity.

Second, are the relatively few studies that attempt to elicit the real demand of WTP for climate protection from a purely individual perspective. Using a similar design to the study herein, Löschel et al. (2013) sold EUAs at different prices to a sample of 202 subjects from the Mannheim population who received $40 €$ for participation. A median WTP of zero and a mean WTP of $12 € / \mathrm{tCO}_{2}$ were found. Essentially, Löschel et al. observe a majority of subjects unwilling to contribute, and a small minority willing to do so irrespective of the associated costs. A similarly framed field experiment with cash incentives was conducted by Diederich and Goeschl (2011) who determined the willingness to abate one $\mathrm{tCO}_{2}$ among the German Internet-using population. In their design, 2,440 participants faced a real trade-off between a 
cash prize and guaranteed emissions reductions through the retirement of EUAs. They estimated a zero median WTP and a mean WTP of about $6 € / \mathrm{tCO}_{2}$.

A third branch of literature related to our approach consists of studies which have investigated the issue of WTP for public goods with regard to the free rider option using a stated preference or experimental approach. Cummings et al. (1997) tested, and rejected, the hypothesis that stated preference (i.e. hypothetical) referenda is incentive compatible and generates the same results as real referenda: A hypothetical referendum leads to more affirmative responses than a real one. Taylor (1998) reports on experiments that implement a theoretically incentive-compatible revelation mechanism, a closed referendum ${ }^{4}$, to elicit responses to valuation questions in both hypothetical and real experiments. As in Cummings et al., evidence of an upward hypothetical bias is found. Taylor et al. (2001) conducted an induced-value laboratory experiment testing the incentive compatibility of the referendum voting mechanism for eliciting WTP for public goods. Aggregate results suggest incentive compatibility in both hypothetical and real referenda. Their conclusion is that the well-known "hypothetical bias" in stated preference studies is not a value elicitation problem, but rather a value formation problem. Champ et al. (2002) empirically investigate the effect of the payment mechanism on contingent values by asking a WTP question with one of three different payment mechanisms: individual contribution, contribution with provision point, and referendum. They state statistical evidence of more affirmative responses in the referendum relative to the individual contribution treatment and some weak statistical evidence of more affirmative responses in the referendum relative to the provision point treatment. Carson et al. (2006) directly test the hypothesis that respondents always tell the truth in stated preference studies. They reject the hypothesis in two different tests. The first of these involves comparing the case of a zero probability of the referendum being binding with the situation of a positive probability. Here they find that a different response is obtained if the probability of a binding referendum is zero in terms of both the mean and variance of the response. This suggests that results obtained for an inconsequential or purely hypothetical case should not be used to make inferences about how stated preference works in the standard consequential case with some positive probability. The second test involves deliberately providing incentives for nontruthful preference revelation. Here they find that the response is different from the incentive compatible case in the theoretically predicted manner. This suggests that agents will take advantage of incentives for preference misrepresentation. Recently, some studies in this

\footnotetext{
${ }^{4}$ In this case, the public good is only provided for the group of experimental subjects.
} 
branch of literature put more emphasize on WTP issues related to climate change. ${ }^{5}$ Wiser (2007) explores the WTP of a sample of U.S. residents for renewable energy under collective and voluntary payment vehicles. He finds that under certain conditions, when confronted with a collective payment mechanism, respondents state a higher WTP than when market-based mechanisms (which rest on individual decisions only) are used. Furthermore, he reports that stated preference responses are strongly correlated with expectations for the WTP of others. Menges and Traub (2009) investigate individual preferences for green electricity under alternative payment vehicles; an individual-choice treatment where subjects act as market participants and a public-choice treatment where the level of green electricity consumed by all subjects was determined by a majority vote. They report a strong treatment effect which highlights the large extent of free riding in the private provision of the public good green electricity. Under the public-choice scenario subjects' WTP was almost three times higher than under the individual-choice treatment. ${ }^{6}$

\section{The experiment}

The aim of our study was to investigate the extent to which a sample of the Mannheim population would be willing to contribute to further climate protection from their own disposable income. To elicit the real WTP for a reduction of atmospheric $\mathrm{CO}_{2}$, an experimental approach of asking people to give up real money as an alternative to the survey approach was implemented. The EU ETS was employed as a vehicle to this end and emission reductions were directly sold to the subjects. The following section presents the procedures used, whereby the baseline treatment BASE is used as a reference. Modifications in the other two treatments, INFO(rmation) and COLL(ective), are explained subsequently.

Participants were recruited following the random distribution of approximately 4,000 letters of invitation in the Mannheim city centre, Germany. The information that people received at this stage was that a survey would be carried out in which they would have the opportunity to buy products and that they would receive remuneration of between $15 €$ and $40 €$ for their time. Since several studies show that if people bid using windfall money they are likely to overstate their WTP (e.g. Cherry 2001, Cherry et al. 2002), it was emphasised in the initial letter that

\footnotetext{
5 Some studies (Champ et al. 1997, Wiser 2007, Menges and Traub 2009) distinguish between the notion of willingness-to-pay (WTP) under a public-choice decision design where free riding is prevented and the lower willingness-to-donate (WTD) under an individual-choice design where free riding incentives will prevent (most) attendants to state their true WTP. In this paper, however, we stick to the WTP notion since the existing literature on the valuation of climate protection usually refers to WTP.

${ }^{6}$ Note that due to different external effects and motives such as concerns against nuclear power or security of supply the public good green electricity is not equivalent to the public good climate protection.
} 
the amount of between $15 €$ and $40 €$ was explicitly remuneration their participation. In this way it was believed that participants would feel entitled to the money. ${ }^{7}$

To elicit the individual demand, the following market mechanism was chosen, being incentive-compatible, relatively simple and capable of creating an individual demand function with two price-quantity-combinations: Each participant was confronted with two different prices for permits in $100 \mathrm{~kg} \mathrm{CO}_{2}$ units ordered from 'high' to 'low'. Subjects were then asked to indicate the quantity of permits they would be willing to buy at each of the prices. Finally, one of the two prices was randomly and openly selected by the administrator and the transaction was carried out at the corresponding price. Participants who did not wish to buy permits at a specific price indicated a quantity of zero.

\section{Table 1: Steps of the experiment}

\begin{tabular}{|c|c|c|}
\hline \# & Step & Explanation \\
\hline 1 & Welcome & $\begin{array}{l}\text { Issuing of instructions and remuneration of } 15 €-40 € \text {, confirmation of } \\
\text { compliance with rules }\end{array}$ \\
\hline 2 & Questionnaire 1 & Socio-economic characteristics and attitudes towards climate change \\
\hline 3 & Instructions & Explanation and presentation of the purchase procedure, example, quiz \\
\hline 4 & Information 1 & Climate change and EU ETS \\
\hline 5 & Information 2 & Purchase option and $\mathrm{CO}_{2}$ emitting activities \\
\hline 6 & Purchase decision & Indication of quantity demanded at two different prices \\
\hline 7 & Questionnaire 2 & Expectations, reasons to buy or not to buy, opinions about climate policy \\
\hline 8 & Public price draw & Random selection and announcement of one price \\
\hline 9 & Payment & Subjects pay their stated quantities (or the median quantity) in private \\
\hline 10 & Leave the institute & \\
\hline
\end{tabular}

The experiment took place in December 2011 on the premises of the Centre for European Economic Research (ZEW) in Mannheim, Germany. A total of 157 participants took part in the experiment and were randomly allocated to the sessions. ${ }^{8}$ The steps of the experiment are listed in Table 1 above. At the beginning of each session, participants received their $40 €$ cash remuneration along with their instructions. ${ }^{9}$ At the same time, subjects confirmed that they would obey the rules given by the research staff during the study. Subsequently, participants

\footnotetext{
${ }^{7}$ Other methods of creating entitlement to the monetary endowment could have been used, e.g. paying out the money some time before the real experiment took place or employing real effort tasks. However, both methods would have increased the complexity and/or the duration of the experiment significantly. Our method of creating entitlement only by emphasizing that the up to $40 €$ were paid as a remuneration for the time subjects spend for the purpose of participation might presumably have led to an overestimation of WTP. According to the German Federal Statistical Office the average wage per hour net of taxes in Germany was $19.59 €$ in 2008.

${ }^{8}$ The actual response rate, however, was higher than $4 \%$ as during the registration process all applications were screened according to gender and age, i.e. people from certain age groups that were already overrepresented in the sample were not permitted to take part.

${ }^{9}$ See Annex I for the questionnaires (including descriptive statistics) and Annex II for the translated instructions (treatment BASE).
} 
were asked to choose a desk from which to answer the survey from. Participants were not permitted to communicate with one another. A research administrator was on hand during each survey session to clarify any questions that arose privately with the participant concerned. Sessions lasted for approximately 60 minutes. At first, participants completed an initial questionnaire enquiring into their socio-economic characteristics and attitudes towards climate change. The purchasing procedure was then explained by use of instructions. Additionally, participants witnessed a first presentation of a tangible (but unrelated to $\mathrm{CO}_{2}$ permits) example of the market mechanism and were asked to fill out a short quiz as verification of their understanding of the procedure. The explanation of the mean and median quantity demanded at a given price (see below) was included in the instructions. Following this stage, participants received information about (i) climate change and its effects on the environment and human society, and (ii) the EU ETS. In the information about the EU ETS emphasis was placed on the fact that buying and withdrawing permits reduces EU emissions. Finally, participants were informed that they had the opportunity to buy permits in $100 \mathrm{~kg} \mathrm{CO}_{2}$ units with their own money and could therefore contribute to the overall reduction of $\mathrm{CO}_{2}$ emissions. Participants were reassured that all transactions would be carried out and that the final purchases and withdrawing of permits would be announced on the ZEW webpage. In order to make individual $\mathrm{CO}_{2}$ emissions more tangible participants were provided with a second presentation with three specific examples of activities resulting in emissions of $100 \mathrm{~kg} \mathrm{CO}{ }_{2}{ }^{10}$ Thereafter, each participant was asked to indicate the quantity of permits they would be willing to purchase at each of the two different prices. In doing so, maximal expenditures were limited to $25 €$. Finally, participants completed a second questionnaire answering questions about expectations regarding the mean and median quantity demanded by all other subjects in the group, possible motives in contributing (or not contributing) to climate protection and general opinions regarding climate policy. After the public price draw, participants left the room and the institute individually. Subjects who had announced purchases of positive quantities of EUAs were requested to pay the corresponding amount of money they had stated in the survey.

The experiment was conducted in six sessions (each with between 17 and 32 participants) and three treatments (see Table 2); two sessions per treatment whilst each of the two price vectors

\footnotetext{
${ }^{10}$ The following examples for activities generating $100 \mathrm{~kg} \mathrm{CO}_{2}$ were chosen: (i) a $720 \mathrm{~km}$ drive with a VW Golf 1.4 TSI, (ii) the electricity consumption of a two-person household in 19 days, and (iii) $0.9 \%$ of the annual average per capita $\mathrm{CO}_{2}$ emissions in Germany.
} 
$\{(350 € C e n t, 150 € C e n t),(250 € C e n t, 50 € C e n t)\}$ were used once per treatment. Thus, there were four different prices for each treatment.

The treatment BASE was virtually identical to Löschel et al. (2013) except for differences in the price vector and the maximal possible expenditures. In treatment INFO, a subset of participants were given information about the real demand behaviour of subjects in the study conducted by Löschel et al. (2013), which was held in March 2010. For this purpose, two price intervals with the mean and median quantity demanded by participants were announced directly before the purchase decision. ${ }^{11}$ Furthermore, the total expenditures, $678 €$, and the overall purchased quantity, $53 \mathrm{tCO}_{2}$, were indicated. In treatment COLL after the public price draw the group's median quantity demanded was calculated and each subject was obliged to buy this amount no matter what his or her revealed demand at this price was. All subjects were informed about the rules of the game before the decision was made.

The total quantity of allowances purchased by the participants equated to $55 \mathrm{tCO}_{2}$ and transactions were directed to the DEHSt account 170-34-34. The sole purpose of this account was to hold and delete the allowances at the end of the calendar year. The entire process was published at the ZEW webpage. ${ }^{12}$

Table 2: Treatments, prices and subjects

\begin{tabular}{|c|c|c|c|c|c|c|}
\hline & & \multicolumn{4}{|c|}{ price (in €Cent) } & \multirow[b]{2}{*}{ Subject } \\
\hline \multirow{5}{*}{ treatment } & \multirow{5}{*}{$\begin{array}{c}\text { BASE } \\
\text { COLL } \\
\text { INFO }\end{array}$} & 50 & 150 & 250 & 350 & \\
\hline & & 17 & 26 & 17 & 26 & 43 \\
\hline & & 32 & 32 & 32 & 32 & 64 \\
\hline & & 29 & 21 & 29 & 21 & 50 \\
\hline & & 78 & 79 & 78 & 79 & 157 \\
\hline
\end{tabular}

\section{Hypotheses}

In our study, we tested two treatment variables: (i) the information subjects receive about real demand of a group of subjects in a similar decision making situation, and (ii) the introduction of collective action whereby the median quantity has to be bought by all subjects.

The expected effect of information on the real demand is ambiguous. On the one hand, one could argue that given information about positive contributions by others has a downward effect on the demand as subjects could free ride on the others" contributions ("crowding out",

\footnotetext{
${ }^{11}$ For price intervals $[20,100]([120,200],[220,300],[320,400]) € C e n t$ the mean quantity demanded was 8.4 $(3.3,1.1,0.8)$ units of $100 \mathrm{~kg} \mathrm{CO}_{2}$. For the same price intervals the median quantity demanded was $1(0,0,0)$.

${ }^{12}$ The real costs for purchasing the (rounded up) $55 \mathrm{tCO}_{2}$ in January 2012 were $55 \mathrm{tCO}_{2} \times 7.20 € / \mathrm{tCO}_{2}=396 €$. The revenue collected by those subjects who completed transactions totaled $803 €$.
} 
e.g. Warr 1982, Robert 1984). On the other hand, if subjects show a strong degree of reciprocity or conditional cooperative behaviour they could "reward" pro-environmental behaviour of others with higher personal contributions (e.g. Sudgen 1984, Fischbacher et al. 2001). Evidence from field experiments (such as Frey and Meier 2004, Shang and Crozon 2009) suggests information about cooperative behaviour of others results in a positive overall effect. However, such experimental evidence is limited to local public goods such as radio stations and local charitable funds, whereas climate protection is a global public good. One could also argue that due to the good's properties the physical impact of the others' contributions is zero, information will be without any effect. Thus, no distinct hypothesis about the decision to buy between INFO and BASE can be derived. ${ }^{13}$

The expected effect of the treatment variable collective action is obvious if we assume that a fraction of subjects are conditional co-operators or show reciprocal behaviour. In BASE, individuals could free ride on the contributions of other subjects and, therefore, strong incentives could exist to understate the demand for the public good. In COLL, free riding within the group is prevented as all subjects are required to purchase the median quantity. Thus, contributions can be expected to be higher in COLL than in BASE. To reiterate however: even the largest possible group contribution in our experiment would still have no noticeable effect on the global public good. This casts serious doubts on this hypothesis.

Nevertheless, taking the empirical evidence from public good games into account (e.g. Sturm and Weimann 2006), positive contributions can be expected in each treatment despite the negligible effect on climate change. First, in BASE and INFO conditional co-operators could trust in the contributions by others and therefore base their contributions on what they expect others will contribute, yielding higher contribution-levels as predicted by the free rider hypothesis. Second, contributions can be explained by social motivations, which are associated with contributing to the good itself rather than to the effect of the contribution (Cooper et al. 2004). For example, people could buy moral satisfaction instead of ascribing an economic value to the public good (Kahneman and Knetsch 1992) or gain from a positive self-image when contributing to a moral cause (Johansson-Stenman and Svedsäter 2010). Another possible explanation is the presence of a 'warm glow motive', which yields positive utility from giving, regardless of the outcome (Crumpler and Grossman 2008). A third string of theory highlights the role of deontology in decision making processes (Spash 2000, 2006).

\footnotetext{
${ }^{13}$ As we follow the No Deception Rule in experimental economics (e.g. Riedl 2011) our treatment INFO allows only one information condition and a control condition (BASE).
} 
People can exhibit deontological values that cause them to neglect consequences, because they decide on the basis of morally mandated duties to do the right thing. This is often presented in contrast to consequentialist orientations of people who focus on the outcome of their action (Tanner 2008).

A commonality of these theories is that they suppose that people receive utility from the act of doing what is morally right itself, independent of the environmental or social impact. Consequentially, positive contributions can be observed for: i) conditional co-operators with high social trust, ii) people exhibiting the mentioned social motivations or iii) people who are motivated by i) and ii). With real financial incentives the individual level of contribution is then defined by the utility gain through contributions. If the utility from making a contribution is higher than the utility from an additional monetary unit, people should contribute until the marginal utility from giving equals the marginal utility of keeping the rest of the endowment. In COLL incentives to contribute change fundamentally. Subjects who experience not only the discussed social motivations, but, to a certain degree, tend to follow the strategy of a conditional co-operator (contribute only if others also contribute) have an additional incentive to cooperate in COLL. They do not need to exhibit high social trust, but are ensured that everybody in the group makes the same contribution, which makes them contribute more when compared to BASE.

\section{Results}

\subsection{Pool of participants and their attitudes towards climate change}

Tables 12 and 13 (Annex I) present the participants' socio-economic characteristics. Our subject pool covered all age groups from 18-75 for men as well as for women. The sample is, however, characterized by an underrepresentation of younger female subjects. ${ }^{14}$ Furthermore, high income groups and selected professional groups are also somewhat underrepresented.

Tables 14-16 (Annex I) present participants' attitudes and experiences with regard to climate change. With respect to the level of information about climate change, more than half of the participants were "reasonably well informed" (59\% of all subjects), and almost one third (28\%) was at least "rather well informed". Regarding climate change matters, $48 \%$ were "rather concerned" about climate change and about $18 \%$ were "very concerned". However, a number of participants remained neutral $(21 \%)$ with respect to this issue or "rather not

\footnotetext{
${ }^{14}$ All comparisons concerning representativeness are based on Chi2 tests with $\mathrm{p}<0.05$ level of significance. The population of the city of Mannheim respectively the country Baden-Württemberg is the population of interest (StaLa BW 2007).
} 
concerned" (12\%). Participants' attitudes differed with respect to the expectation of negative consequences caused by climate change for their own personal life: $52 \%$ expected negative consequences, $47 \%$ did not. Positive consequences caused by climate change were only expected by $11 \%$ whereas $86 \%$ of the sample did not expect positive effects.

Among the participants there seemed to be the awareness that inter-generational equity may be affected by climate change. Whilst $17 \%$ stated that climate change poses a "serious threat" to themselves or their families, $25 \%$ stated, that climate change poses a threat to their children and $80 \%$ to future generations in general. Furthermore, transnational equity was also seen to be an issue as $29 \%$ of the participants found climate change a "serious threat" to people in Germany, 44\% stated that climate change poses a threat to people in other industrialised countries and $76 \%$ indicated that climate change is a threat to people in developing countries.

The relative majority of the participants (44\%) thought that the impacts of climate change were already visible whilst $38 \%$ expected that the impacts would become visible within the next 50 years. The overwhelming majority (86\%) supported the statement that "there is still a need for commitment to fight climate change". Only $10 \%$ disagreed with this statement. Participants were also asked who they thought should be responsible for implementing measures against climate change. Participants were convinced that their "personal behaviour has an influence on climate change” (68\% agreement). Moreover, 69\% agreed with the statement that their behaviour in attempting to prevent climate change "can encourage others ... to behave the same way". Furthermore, $82 \%$ did not agree with the statement that "the government is solely responsible for measures against climate change”.

\subsection{Attitudes toward climate change}

Several questions were included in the questionnaire to elicit the respondents' attitudes towards climate change. Some of these questions were taken from a previous study from Carlsson et al. (2012), who collected data for the USA, Sweden and China, and the corresponding results are presented in Table 3.15 Compared to China and Sweden a large share of our sample (17\%) believed that the global temperature had not increased. $80 \%$ agreed that humans have caused the temperature increase and also about $80 \%$ believed that mitigation is possible. About $70 \%$ said that Germany should reduce emissions, even if other

\footnotetext{
15 As well as in our experiment, Carlsson et al. (2012) presented stylized facts about climate change from the IPCC after eliciting attitudes towards climate change, so answers are not influenced by different information from the experimenter.
} 
countries did not make similar efforts. This is the same share of respondents as in the USA, but less than in China and Sweden. The sample was divided in their opinion as to whether a reduction should take place in Germany or in other countries, where reduction might be cheaper. Furthermore, there was a preference for reduction rather than adaptation, but adaptation was still favored by more than $30 \%$. As in the USA, only a minority was prepared to risk jobs to achieve environmental goals. The information of the survey was regarded trustworthy by most of the respondents.

Interestingly, in many key aspects the Mannheim population seemed to share attitudes expressed by participants in the USA. Notably, in Mannheim and the US a much larger share of the population believes that there was no temperature increase compared to those surveyed in Sweden and China. Moreover, mitigation is the favourable option for only about $60 \%$ of Germans and Americans, in contrast to more than $80 \%$ of Swedes and Chinese. Furthermore, Germans, like Americans, are less willing to sacrifice jobs in order to preserve the environment. In Germany, there is an exceptionally high population share that regards to adaptation as an important strategy to deal with climate change.

Table3: Attitudes toward climate change: Share that agreed to statement

\begin{tabular}{|c|c|c|c|c|}
\hline \multirow[b]{2}{*}{ Description of statement } & \multirow[b]{2}{*}{$\begin{array}{c}\text { Mannheim } \\
(\mathrm{n}=157)\end{array}$} & \multicolumn{3}{|c|}{ Results from Carlsson et al. (2012) } \\
\hline & & $\begin{array}{c}\text { Sweden } \\
(\mathrm{n}=1,230)\end{array}$ & $\begin{array}{c}\text { USA } \\
(\mathrm{n}=999)\end{array}$ & $\begin{array}{c}\text { China } \\
(\mathrm{n}=1,264)\end{array}$ \\
\hline a) The temperature has not increased globally. & 0.17 & 0.06 & 0.24 & 0.05 \\
\hline $\begin{array}{l}\text { b) Humans have affected the temperature } \\
\text { increase. }\end{array}$ & 0.80 & 0.94 & 0.73 & 0.96 \\
\hline c) We cannot do anything to stop climate change. & 0.08 & 0.06 & 0.17 & 0.10 \\
\hline d) We can mitigate, but not stop climate change. & 0.77 & 0.80 & 0.60 & 0.79 \\
\hline e) We can stop climate change. & 0.08 & 0.12 & 0.11 & 0.09 \\
\hline $\begin{array}{l}\text { f) Our own country should reduce carbon } \\
\text { emissions, even if other countries do not reduce } \\
\text { their carbon emissions. }\end{array}$ & 0.68 & 0.82 & 0.68 & 0.80 \\
\hline $\begin{array}{l}\text { g) Our own country should primarily use public } \\
\text { funding to reduce carbon emissions wherever it is } \\
\text { cheapest, even if it means in another country. }\end{array}$ & 0.47 & 0.45 & 0.16 & 0.32 \\
\hline $\begin{array}{l}\text { h) Our own country should primarily use public } \\
\text { funding to reduce carbon emissions in own } \\
\text { country. }\end{array}$ & 0.47 & 0.39 & 0.43 & 0.56 \\
\hline $\begin{array}{l}\text { i) Countries in the world should deal with climate } \\
\text { change primarily by reducing carbon emissions. }\end{array}$ & 0.59 & 0.86 & 0.59 & 0.83 \\
\hline $\begin{array}{l}\text { j) Countries in the world should deal with climate } \\
\text { change primarily by adaptation. }\end{array}$ & 0.31 & 0.10 & 0.16 & 0.15 \\
\hline $\begin{array}{l}\text { k) The information given in the survey regarding } \\
\text { climate change is trustworthy. }\end{array}$ & 0.75 & 0.82 & 0.50 & 0.88 \\
\hline $\begin{array}{l}\text { 1) We should prioritise environmental } \\
\text { improvements, even if we lose jobs. }\end{array}$ & 0.36 & 0.62 & 0.40 & 0.77 \\
\hline
\end{tabular}




\subsection{Mean and median quantities}

Figure 1 shows the individual demand curves for the abatement of $100 \mathrm{~kg} \mathrm{CO}$ across the three treatments BASE, INFO and COLL for the two price vectors $(50,250)$ and $(150,350)$, as well as mean demand curves. ${ }^{16}$ The demand curves for the lower price vector are much steeper than for the higher price vector and the variance decreases with price. ${ }^{17}$ This is partly because of the experimental design, where maximum expenditure was fixed at $25 €$ and therefore the maximum quantity for the price of $50 € C$ ent was 50 certificates and for the price of $350 € C e n t$ the maximum amount was seven.

Figure 1: Individual demand curves

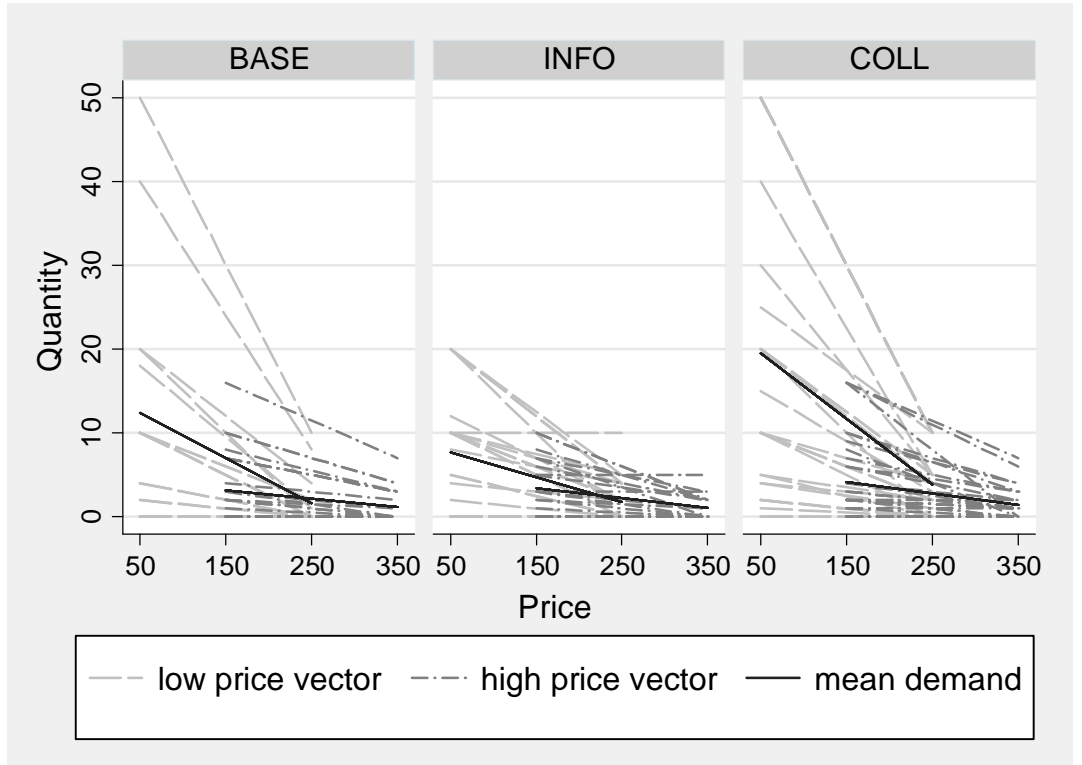

For the lower price vector $(50,250)$, average quantities are much higher in COLL, but the difference between treatments gets smaller as the price increases. The mean demand curves of BASE and INFO are very similar and, according to a two-sample Wilcoxon rank-sum test, not significantly different at all bidding points. The largest treatment difference can be found between BASE and COLL for 50€Cent, where mean demand is as high as 12.4 and 19.5 for BASE and COLL, respectively. The difference is relatively large, but according to a two-

\footnotetext{
16 Three individuals who did not state demanded quantities at both prices are henceforth excluded from the analyses.

${ }^{17}$ Variances decrease gradually from $50 € C e n t$ to $150 € C e n t$ for all treatments $(\mathrm{p}<0.01)$, from $150 € C$ ent to $250 € C$ ent for INFO $(\mathrm{p}<0.05)$ and from $250 € C$ ent to $350 € C$ ent for INFO and COLL $(\mathrm{p}<0.05)$ using the Levene's robust test statistic.
} 
sample Wilcoxon rank-sum test not significant. The only significant difference between COLL and BASE can be found for $250 € C e n t(p<0.05) .{ }^{18}$

A similar picture arises for the median values which are given along with the means in Table 4. The differences between treatments in median quantities are much smaller than the corresponding differences in mean quantities.

Table 4: Mean and median quantities across treatments

\begin{tabular}{lrrrrr}
\hline & \multicolumn{3}{c}{ Mean quantity at given price (standard deviation) } \\
\cline { 2 - 6 } Treatment & 50€Cent & 150€Cent & 250€Cent & 350€Cent & Total \\
\cline { 2 - 6 } BASE $(\mathrm{n}=86)$ & $12.4(14.1)$ & $3.2(4.3)$ & $1.6(3.0)$ & $1.2(1.9)$ & $4.1(7.9)$ \\
INFO $(\mathrm{n}=98)$ & $7.7(7.2)$ & $3.4(3.4)$ & $1.8(2.4)$ & $1.1(1.4)$ & $3.7(5.1)$ \\
COLL $(\mathrm{n}=124)$ & $19.5(18.1)$ & $4.2(4.9)$ & $3.9(3.8)$ & $1.4(1.8)$ & $7.1(11.8)$ \\
Total $(\mathrm{n}=308)$ & $13.5(14.8)$ & $3.6(4.3)$ & $2.6(3.3)$ & $1.2(1.7)$ & $5.2(9.2)$ \\
\hline \multicolumn{7}{c}{ Median quantity at given price } & & & \\
\cline { 2 - 6 } Treatment & $50 € C e n t$ & 150€Cent & 250€Cent & $350 € C e n t$ & Total \\
BASE $(\mathrm{n}=86)$ & 10.0 & 1.5 & 0.0 & 0.0 & 1.0 \\
INFO $(\mathrm{n}=98)$ & 9.0 & 3.0 & 0.0 & 0.0 & 2.0 \\
COLL $(\mathrm{n}=124)$ & 12.5 & 2.0 & 2.5 & 1.0 & 2.0 \\
Total $(\mathrm{n}=308)$ & 10.0 & 2.0 & 2.0 & 0.0 & 2.0 \\
\hline
\end{tabular}

To test for differences in the mean demand curves a Somer's D analysis is used, because it is rank based, but allows for clustered data as opposed to the Wilcoxon ranksum test, which assumes independent observations (Newson 2002, 2006).

Table 5: Somer's D coefficient of treatments on quantity

\begin{tabular}{llllll}
\hline Group variable & Coef. & SE & $\mathrm{z}$ & $\mathrm{P}>\mathrm{z}$ & {$[95 \% \mathrm{CI}]$} \\
\hline INFO vs. BASE & 0.06 & 0.10 & 0.60 & 0.55 & {$[-0.14,0.25]$} \\
COLL vs. BASE & 0.22 & 0.09 & 2.30 & 0.02 & {$[0.03,0.40]$} \\
\hline
\end{tabular}

Note: Cluster adjusted standard errors

Table 5 reports the Somer's D coefficients, for INFO and COLL along with their significance levels and confidence intervals. The Somer's D coefficient is significant for the COLL treatment, meaning that the quantity bought is larger in COLL than in BASE. The interpretation of the confidence interval is as follows: Given a randomly-chosen subject in COLL and a randomly-chosen subject in BASE, the subject in COLL is, with 95\% confidence, $3 \%$ to $40 \%$ more likely to buy more certificates compared to a subject in BASE.

\footnotetext{
${ }^{18}$ Because each participant stated two price-quantity combinations a simple likelihood ratio test cannot be performed on the pooled bid points to test for pairwise equality of mean demand across treatments.
} 
The INFO treatment does not have an effect on demand compared to BASE. It is, nevertheless, useful to compare buying behaviour between INFO and the study where the information is taken from. Averaging of the price vectors from Löschel et al. (2013) yields about the same bidding points as used in INFO, making the mean quantities in both studies comparable. ${ }^{19}$ In Löschel et al., for the adapted price range, with bidding points from $20 € C$ Cent to $400 € C$ ent, mean quantity was 3.4 units of $100 \mathrm{~kg} \mathrm{CO}_{2}$. Therefore demand in INFO is $8.8 \%$ higher than in the study where the information is derived. To test for the differences in both groups Somer's D coefficient is again used, because of the different cluster structure in both studies. Table 6 shows that the group difference is significant and a randomly chosen subject of INFO has a higher probability (from $4 \%$ to $33 \%$ ) to buy more certificates, thus "rewarding" pro-environmental behaviour of others with higher personal contributions. Note that the difference in INFO cannot be explained by possible confounding factors of the second study as group differences between BASE and the first study are not significant at $p<0.10$.

Table 6: Somer's D coefficient of quantities against Löschel et al. (2013) data

\begin{tabular}{llllll}
\hline Group variable & Coef. & SE & $\mathrm{z}$ & $\mathrm{P}>\mathrm{z}$ & {$[95 \% \mathrm{CI}]$} \\
\hline INFO vs. Löschel et al. data & 0.19 & 0.07 & 2.52 & 0.01 & {$[0.04,0.33]$} \\
BASE vs. Löschel et al. data & 0.13 & 0.07 & 1.64 & 0.10 & {$[-0.02,0.28]$} \\
\hline
\end{tabular}

Note: Cluster adjusted standard errors

From the price quantity combinations the average WTP can be calculated by interpreting an accepted bid offer as minimum WTP. A bid offer was accepted if the amount at a given price is larger than zero. For non-acceptance a zero WTP was assumed. We then find an overall mean WTP of $11.0 € / \mathrm{tCO}_{2}$. The mean WTP for BASE, INFO and COLL are 9.1€, 10.0€, and $13.3 €$ respectively. ${ }^{20}$ These values are close to the mean WTP of $11.9 € / \mathrm{tCO}_{2}$ found by Löschel et al. (2013) in a similar experimental setting. The overall median WTP from the distribution of individual WTPs is $5 € / \mathrm{tCO}_{2}$. The median WTP for both BASE and INFO is found to be $5 € / \mathrm{tCO}_{2}$ as well, whilst for COLL, the median WTP raises to $10 € / \mathrm{tCO}_{2}$.

Table 7 gives the row percentages of WTPs across treatments. In COLL, less than $30 \%$ have a WTP of zero compared to almost $50 \%$ in BASE. Also shares for positive WTPs are higher in COLL than in BASE. Disregarding the cluster structure, the difference of the distribution

\footnotetext{
19 See footnote 11.

${ }^{20}$ Another way to calculate mean WTP is to divide the sum of expenditures $(1,763 €)$ with the total quantity demanded $\left(159 \mathrm{tCO}_{2}\right)$. Thus mean WTP over all treatments equals $11.1 € / \mathrm{tCO}_{2}$. The treatment allocation does not change WTP considerably. The mean WTP for BASE, INFO and COLL are 11.5€, 11.7€, and 10.7€ respectively. WTP for COLL is smaller because subjects buy more, especially at a lower price, making expenses grow slower than quantity.
} 
between BASE and COLL is significant at $\mathrm{p}<0.05$ according to a Chi2 test and a Kolmogorov-Smirnov test. ${ }^{21}$ The free riding effect in BASE is therefore significant and leads to a 32\% lower WTP relative to COLL. Compared to the results from Menges and Traub (2009), who find that the WTP is three times higher in a public choice treatment, our free riding effect is relatively small.

Table 7: Distributions of WTP across treatments

\begin{tabular}{lccccc}
\hline & \multicolumn{5}{c}{ Shares of WTP across treatments in percent } \\
Treatment & 0€Cent & 50€Cent & 150€Cent & 250€Cent & 350€Cent \\
\cline { 2 - 6 } BASE $(\mathrm{n}=86)$ & 48.8 & 16.3 & 16.3 & 7.0 & 11.6 \\
INFO $(\mathrm{n}=98)$ & 42.9 & 19.4 & 14.3 & 13.3 & 10.2 \\
COLL $(\mathrm{n}=124)$ & 27.4 & 22.6 & 18.6 & 16.9 & 14.5 \\
Total & 38.3 & 19.8 & 16.6 & 13.0 & 12.3 \\
\hline
\end{tabular}

\subsection{Expectations of mean and median values}

Table 8 shows the mean of the expected quantities purchased by other subjects. Expectations of other's contributions ${ }^{22}$ are lowest in INFO and highest in COLL, but in comparison to BASE none of the differences are significant at $\mathrm{p}<0.05$. Thus, the treatments did not influence expectations.

Comparing the expected with the actual quantities in Table 8, it can be seen that average expectations are usually higher than actual demand, except for COLL. To test for differences between expectations and own contributions, data clustering must again be taken into account. There are two within-subject comparisons per individual, while the matched pairs rank test treats them as independent observations, therefore artificially increasing sample size and decreasing $\mathrm{p}$ values. The analysis can be performed without clustering if the sample is divided into price groups $(50,150)$ and $(250,350)$. The differences are summarized in Figure 2.

\footnotetext{
21 Taking the cluster structure into account the corresponding Somer's D coefficient yields the same significance level.

16 observations were excluded, because they stated higher expected mean or median demand than allowed by the budget restriction. This might have occurred, because the questionnaire didn't repeat the maximum amount of certificates.
} 
Table 8: Expected mean and median quantities

\begin{tabular}{lrrrrr}
\hline & \multicolumn{4}{c}{ Mean expected mean quantity at given price (standard deviation) } \\
\cline { 2 - 6 } Treatment & $50 €$ Cent & $150 € C$ Cent & 250€Cent & 350€Cent & Total \\
\cline { 2 - 6 } BASE $(\mathrm{n}=75)$ & $11.3(8.1)$ & $6.0(4.4)$ & $2.6(2.0)$ & $2.6(2.0)$ & $5.6(5.8)$ \\
INFO $(\mathrm{n}=91)$ & $10.5(7.7)$ & $4.9(3.6)$ & $2.6(1.7)$ & $1.7(1.2)$ & $5.1(5.7)$ \\
COLL $(\mathrm{n}=119)$ & $13.7(9.2)$ & $5.9(3.1)$ & $4.4(2.9)$ & $2.6(1.7)$ & $6.6(6.5)$ \\
Total $(\mathrm{n}=285)$ & $12.0(8.4)$ & $5.7(3.7)$ & $3.3(2.4)$ & $2.4(1.7)$ & $5.9(6.1)$ \\
\hline & \multicolumn{7}{r}{ Mean expected median quantity at given price } & & \\
\cline { 2 - 6 } Treatment & $50 € C e n t$ & $150 € C$ Cent & 250€Cent & $350 € C e n t$ & Total \\
BASE $(\mathrm{n}=81)$ & 8.9 & 4.8 & 2.8 & 2.3 & 4.5 \\
INFO $(\mathrm{n}=96)$ & 8.4 & 2.8 & 2.8 & 1.0 & 4.0 \\
COLL $(\mathrm{n}=119)$ & 14.7 & 5.1 & 4.1 & 2.1 & 6.4 \\
Total $(\mathrm{n}=296)$ & 11 & 4.3 & 3.3 & 1.9 & 5.1 \\
\hline
\end{tabular}

Obviously, subjects expect others to contribute, but in BASE and INFO people contribute systematically less than they expect others to contribute at both high and low prices. This result can be explained by free riding behaviour. Contrary to that, there are no significant differences between contributions and expectations in COLL for the low price of either $50 € C$ ent or $150 € C e n t$. However, this changes with the second price. At the high price of either $250 € C$ ent or $350 € C$ ent people expect others to contribute more than themselves, as is the case in the other two treatments BASE and INFO. ${ }^{23}$

Figure 2: Mean and expected mean quantity

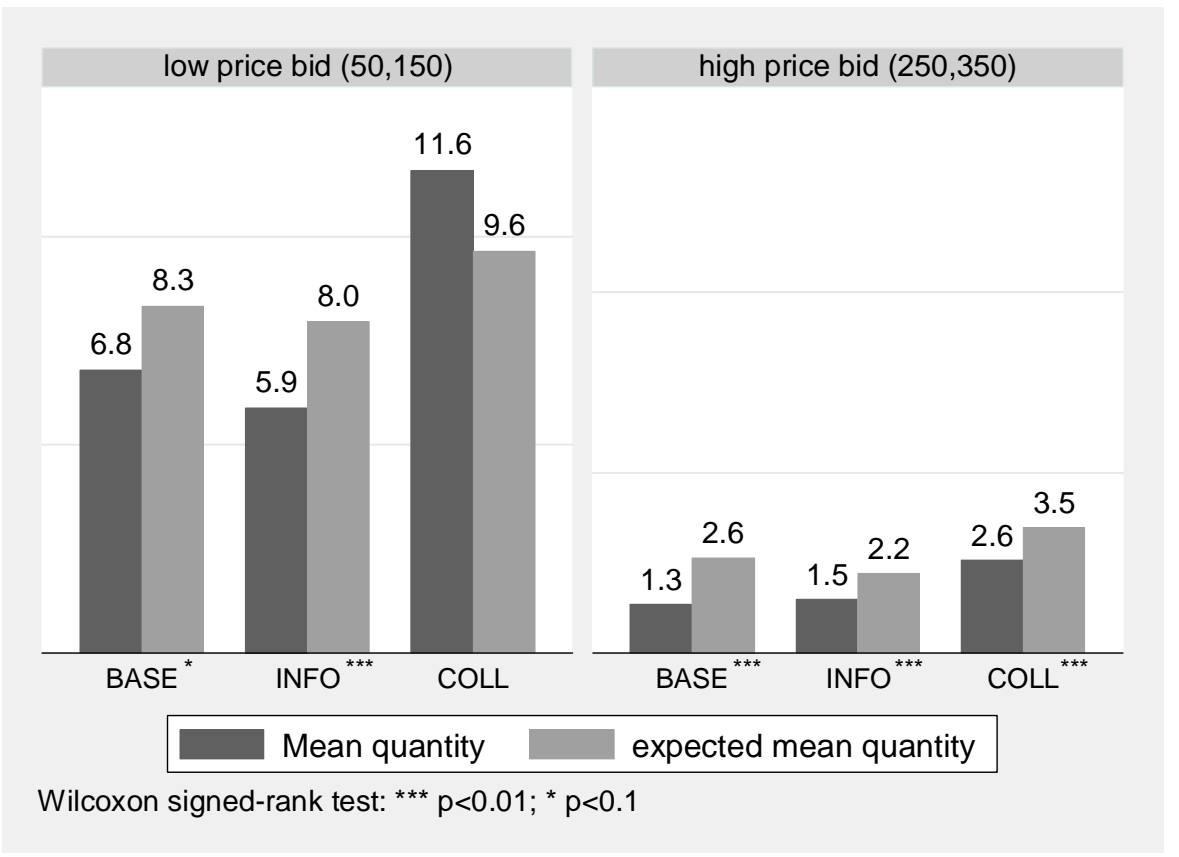

23 Ignoring the cluster structure leads to similar results for BASE and INFO but in COLL actual demand is significantly higher than expectations: $\operatorname{Real}_{\mathrm{COLL}}(7.1)>\operatorname{Exp}_{\mathrm{COLL}}(6.6)$ with $\mathrm{p}<0.05$. 
The results for the first two treatments can be related with the findings in the literature. Lusk and Norwood (2009a) find that people's prediction about voting behaviour of others for a public good are similar to their own actual behaviour if the good is not associated with normative motivations. Additionally, Lusk and Norwood (2009b) find that, if the good is associated with normative motivations, the stated WTP for environmentally friendly groceries is higher than predicted WTP of others. Carlsson et al. (2010) confirm this relationship for donations to charity. They explain their results with the observed tendency to retain flattering self-images by stating to behave more generously than others.

In contrast to these studies, we surveyed demand and expected demand by others under real transactions and find the opposite relationship between personal demand and expected demand by others. The studies are comparable, because buying environmentally friendly goods and making charity donations are contributions to public goods, as the benefit of a preserved environment and the presence of the good cause of the charity can be enjoyed by everybody. We then observe free riding behaviour under real incentives and not in hypothetical contexts. This could be because social motivations like self-enhancement is costly in our design, leading to less than average contributions, if marginal utility from a positive self-image is lower than marginal utility from a monetary unit. This leads to a possible explanation of why people should contribute to climate protection when the marginal effect from the contribution is infinitesimal: If people suffer a disutility from falling to far behind from what they think an average person would or should do, they contribute a positive amount up to the level where their marginal disutility from falling behind equals the marginal utility from income not spend on the public good.

This requires that subjects orientate their level of contributions on what they believe others do. Indeed there are strong correlations between own contributions and expectations about the other's behaviour as shown in Figure 3, where demanded quantity is plotted against expected mean demand. The correlation between personal demand and the expected mean demand of others is larger for the lower price vector, with Spearman's rank correlation coefficients of $\mathrm{r}_{\mathrm{s}(50)}=0.61$ and $\mathrm{r}_{\mathrm{s}(250)}=0.55$ than for the higher price vector with $\mathrm{r}_{\mathrm{s}(150)}=0.44$ and $\mathrm{r}_{\mathrm{s}(350)}=0.45$. All correlations are significant with $\mathrm{p}<0.01$. 
Figure 3: Correlation between demand and expected average quantity

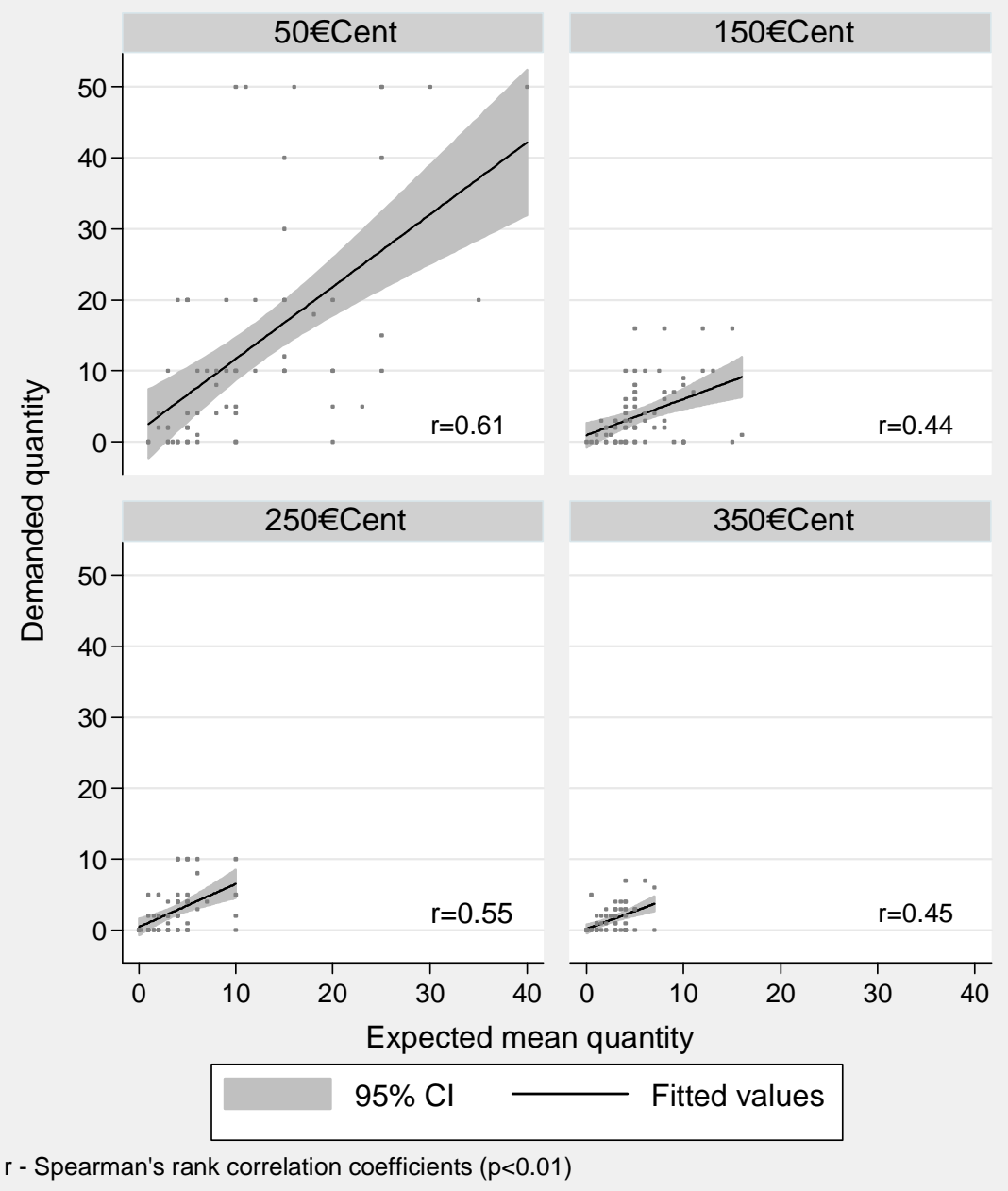

\subsection{Regression results}

In order to elicit the possible determinants of demand for $\mathrm{CO}_{2}$ reduction we conducted a regression analysis. The dependent variable, quantity of $\mathrm{CO}_{2}$ reduction, is highly skewed and non-normal even after a logistic transformation. Therefore, it is preferable to estimate a hurdle or two-part model, where the decision to contribute and how much to buy are modelled separately. This is done by using a probit model to estimate the probability to buy and then an OLS regression for individuals with positive demand that is adjusted by the inverse Mills' ratio (Wooldridge 2009). In a first step to estimate the demand for climate protection, we compare four probit models with each other: three probit models with clustered standard errors and one random effects probit model with bootstrapped standard errors. 


\subsubsection{Comparison of coefficients}

The coefficients of the four probit models are presented in Table 9. The dependent variable is q_d, which indicates whether an individual bought permits or not. All models are pooled over treatments. The first three models have clustered standard errors and the fourth model is a random effects (RE) model with bootstrapped standard errors. ${ }^{24}$ The first model contains only demographic variables and an indicator of whether subjects believed that their personal action had an effect on climate change. This indicator has, contrary to the findings of Löschel et al. (2013), no significant effect in all the specifications. The second model contains the information from subjective beliefs, such as whether the global temperature has increased and whether humans have affected this increase. The third model additionally checks for other attitudinal questions and personal opinions that are more significant for our data. The fourth model is uses the predictors of model 3 and imposes a random effects structure.

Most variables that are significant in one of the models are also significant in other model specifications. The treatment indicator COLL is significant with a positive sign in all models, indicating a positive relationship between collective decision making and the decision to contribute to climate protection. ${ }^{25}$ This confirms our hypothesis of a higher propensity to contribute with a collective decision frame, which (partly) rules out free riding.

This result provides further evidence for the free riding reduction through collective decision making, which was also observed by Menges and Traub (2009) for the case of provision of green electricity.

\footnotetext{
${ }^{24}$ The RE model was estimated with 64 integration points and 200 bootstrap repetitions.

25 The coefficient for COLL is also significant in model $3(\mathrm{p}<0.1)$ when tested against the BASE treatment only (see Table 18 in Annex III).
} 
Table 9: Probit specification

\begin{tabular}{|c|c|c|c|c|}
\hline \multirow{2}{*}{$\begin{array}{l}\text { Dependent variable: } \text { q_d } \\
\text { Variable }\end{array}$} & \multicolumn{3}{|c|}{ Clustered SE } & \multirow{2}{*}{$\begin{array}{l}\text { RE SE } \\
\text { Model } 4\end{array}$} \\
\hline & Model 1 & Model 2 & Model 3 & \\
\hline $\ln (\mathrm{p})$ & $\begin{array}{l}-0.53^{* * *} \\
(0.09)\end{array}$ & $\begin{array}{l}-0.53^{* * *} \\
(0.10)\end{array}$ & $\begin{array}{l}-0.58^{* * *} \\
(0.11)\end{array}$ & $\begin{array}{l}-5.84^{\text {*** }} \\
(0.92)\end{array}$ \\
\hline \multicolumn{5}{|l|}{ Demographics } \\
\hline Single & $\begin{array}{l}-0.71^{* *} \\
(0.30)\end{array}$ & $\begin{array}{l}-0.75^{* *} \\
(0.33)\end{array}$ & $\begin{array}{l}-0.82^{* *} \\
(0.33)\end{array}$ & $\begin{array}{l}-7.63^{* *} \\
(3.46)\end{array}$ \\
\hline Female & $\begin{array}{c}0.07 \\
(0.21)\end{array}$ & $\begin{array}{c}0.04 \\
(0.22)\end{array}$ & $\begin{array}{l}-0.07 \\
(0.24)\end{array}$ & $\begin{array}{l}-0.37 \\
(2.55)\end{array}$ \\
\hline Age & $\begin{array}{l}-0.02^{*} \\
(0.01)\end{array}$ & $\begin{array}{l}-0.02^{*} \\
(0.01)\end{array}$ & $\begin{array}{l}-0.02^{* * *} \\
(0.01)\end{array}$ & $\begin{array}{l}-0.21^{* *} \\
(0.11)\end{array}$ \\
\hline Children in household (yes/no) & $\begin{array}{l}-0.94^{* * *} \\
(0.36)\end{array}$ & $\begin{array}{l}-1.04^{* * *} \\
(0.37)\end{array}$ & $\begin{array}{l}-1.07^{* * *} \\
(0.36)\end{array}$ & $\begin{array}{c}-10.29^{* *} \\
(4.01)\end{array}$ \\
\hline Education (high/low) & $\begin{array}{c}0.04 \\
(0.21)\end{array}$ & $\begin{array}{c}0.07 \\
(0.22)\end{array}$ & $\begin{array}{l}-0.01 \\
(0.22)\end{array}$ & $\begin{array}{c}0.27 \\
(1.99)\end{array}$ \\
\hline Working (yes/no) & $\begin{array}{c}0.26 \\
(0.23)\end{array}$ & $\begin{array}{c}0.27 \\
(0.23)\end{array}$ & $\begin{array}{c}0.27 \\
(0.25)\end{array}$ & $\begin{array}{l}2.48 \\
(2.40)\end{array}$ \\
\hline Income (7 groups) & $\begin{array}{c}0.05 \\
(0.08)\end{array}$ & $\begin{array}{c}0.07 \\
(0.08)\end{array}$ & $\begin{array}{c}0.08 \\
(0.09)\end{array}$ & $\begin{array}{c}0.70 \\
(0.94)\end{array}$ \\
\hline $\begin{array}{l}\text { Member in environmental organization } \\
\text { (yes/no) }\end{array}$ & $\begin{array}{c}0.31 \\
(0.32)\end{array}$ & $\begin{array}{c}0.40 \\
(0.34)\end{array}$ & $\begin{array}{l}-0.04 \\
(0.33)\end{array}$ & $\begin{array}{l}-1.31 \\
(3.69)\end{array}$ \\
\hline Opinions and attitudes & & & & \\
\hline $\begin{array}{l}\text { Personal behavior has influence on CC } \\
\text { (yes/no or don't know) }\end{array}$ & $\begin{array}{c}0.06 \\
(0.23)\end{array}$ & $\begin{array}{l}-0.10 \\
(0.23)\end{array}$ & $\begin{array}{l}-0.13 \\
(0.24)\end{array}$ & $\begin{array}{l}-0.66 \\
(2.50)\end{array}$ \\
\hline $\begin{array}{l}\text { Still need for commitment to tackle CC } \\
\text { (yes/no or don't know) }\end{array}$ & & $\begin{array}{c}0.41 \\
(0.32)\end{array}$ & $\begin{array}{c}0.24 \\
(0.33)\end{array}$ & $\begin{array}{l}1.70 \\
(3.34)\end{array}$ \\
\hline $\begin{array}{l}\text { Temperature has not increased globally } \\
\text { (agree/don't agree or don't know) } \\
\text { Humans affected the temperature } \\
\text { increase (agree/don't agree or don't } \\
\text { know) }\end{array}$ & & $\begin{array}{c}0.13 \\
(0.30) \\
0.45^{*} \\
(0.27)\end{array}$ & & \\
\hline $\begin{array}{l}\text { Informational status about CC ( } 4 \text { point } \\
\text { scale) }\end{array}$ & & & $\begin{array}{l}0.38^{*} \\
(0.20)\end{array}$ & $\begin{array}{l}3.75^{*} \\
(1.95)\end{array}$ \\
\hline Worried about CC (5 point scale) & & & $\begin{array}{l}0.22^{* *} \\
(0.11)\end{array}$ & $\begin{array}{l}1.90^{*} \\
(1.09)\end{array}$ \\
\hline $\begin{array}{l}\text { CC poses a serious threat to people in } \\
\text { developing countries (yes/no) }\end{array}$ & & & $\begin{array}{l}0.61^{* *} \\
(0.30)\end{array}$ & $\begin{array}{l}5.57^{*} \\
(3.05)\end{array}$ \\
\hline Treatment indicators & & & & \\
\hline INFO & $\begin{array}{c}0.12 \\
(0.26)\end{array}$ & $\begin{array}{c}0.15 \\
(0.26)\end{array}$ & $\begin{array}{l}0.18 \\
(0.27)\end{array}$ & $\begin{array}{l}1.61 \\
(2.67)\end{array}$ \\
\hline COLL & $\begin{array}{l}0.57^{* *} \\
(0.27)\end{array}$ & $\begin{array}{l}0.58^{* *} \\
(0.28)\end{array}$ & $\begin{array}{l}0.68^{* *} \\
(0.27)\end{array}$ & $\begin{array}{l}6.91^{* *} \\
(2.70)\end{array}$ \\
\hline Constant & $\begin{array}{l}3.56^{* * *} \\
(0.77)\end{array}$ & $\begin{array}{l}3.00^{* * *} \\
(0.83)\end{array}$ & $\begin{array}{l}1.91^{* *} \\
(0.96)\end{array}$ & $\begin{array}{l}20.07^{* *} \\
(9.21)\end{array}$ \\
\hline $\ln \operatorname{sig} 2 \mathrm{u}$ & & & & $\begin{array}{l}4.56^{* * *} \\
(0.31)\end{array}$ \\
\hline$\rho$ & & & & 0.99 \\
\hline McFadden's adj. R2 & 0.024 & 0.023 & 0.065 & . \\
\hline$N$ & 280 & 274 & 270 & 270 \\
\hline
\end{tabular}

A negative price effect is, as expected, observed and is highly significant in all models. Only few demographic variables have influence on the decision to buy permits. Single households and households with children have a lower probability to buy. Age has a negative effect on the probability to contribute. The negative age effect on the WTP for climate protection is also found in other studies, such as Hersch und Viscusi (2006). Income and education have no 
effect, nor has the membership to an environmental organisation. ${ }^{26}$ People that either feel well informed, or are worried about climate change and think that climate change poses a threat to people in developing countries are more likely to purchase permits.

For further analyses the clustered standard errors model is preferred for two reasons: First, the number of clusters in model 3 is 135 and therefore high enough not to produce downward biased standard errors (Cameron et al. 2008). Second, the model fit of the cluster-model is much better (see Annex IV). ${ }^{27}$ Therefore results from the random effects model will not be presented here. Table 10 shows the average partial effect for model 3 for the significant predictor variables. For example, if every subject had received the COLL treatment, the average predicted probability to buy would have been 21 percentage points higher. The confidence interval shows that moving a random subject from BASE to COLL would increase probability to buy more from $5 \%$ up to $37 \%$. Single households have a 24 percentage points lower probability to purchase than non-single households. The effect of price is given as a constant semi-elasticity and thus can be interpreted as a change of the probability to buy as price increases by one percent. Thus a $100 \%$ increase of price, e.g. from 50€Cent to $100 € C e n t$, decreases the probability to buy by 18 percentage points.

Table 10: Average partial effects

\begin{tabular}{llll}
\hline & \multicolumn{3}{c}{ Model 3 } \\
\cline { 2 - 4 } Variables & $\mathrm{dy} / \mathrm{dx}$ & $\mathrm{SE}$ & {$[95 \% \mathrm{CI}]$} \\
\hline $\ln ($ price $)$ & $-0.18^{* * *}$ & 0.03 & {$[-0.24,-0.12]$} \\
Single & $-0.24^{* * *}$ & 0.08 & {$[-0.40,-0.07]$} \\
Children in household & $-0.33^{* * *}$ & 0.10 & {$[-0.52,-0.13]$} \\
Informational status about CC & $0.12^{*}$ & 0.06 & {$[-0.00,0.23]$} \\
Worried about CC & $0.07^{* *}$ & 0.03 & {$[0.01,0.13]$} \\
CC is threat to people in & $0.18^{* *}$ & 0.08 & {$[0.01,0.36]$} \\
developing countries & & & \\
Treatment indicators & & & \\
$\quad$ INFO & 0.06 & 0.09 & {$[-0.11,0.23]$} \\
$\quad$ COLL & $0.21^{* *}$ & 0.08 & {$[0.05,0.37]$} \\
\hline$* p<0.1 ; * * p<0.05 ; * * * p<0.01, \mathrm{CC}-$ climate change.
\end{tabular}

A more direct approach to interpret the effect of prices on the probability to buy is to calculate the predicted probabilities for different price levels across the treatments BASE and COLL

\footnotetext{
${ }^{26}$ A coefficient of green voters was not included as there are almost $15 \%$ missing answers to question Q1.9 (Table 13 in Annex I) and the effect was not significant throughout the models. The indicator for "Member of environmental organization" should therefore work as a proxy for environmentalism.

${ }^{27}$ The RE model yields about the same significance levels for the coefficients as the model with cluster-robust standard errors. Therefore, the RE model does not add efficiency to the analysis and we discuss only the estimates for the cluster robust models. Nevertheless the results from the RE models are qualitatively not different from the ones we describe here and they can be found in Annex III.
} 
which are shown in Figure 4. It can be seen, that the decrease in probability is similar in both treatments and that the decrease is non-linear.

Figure 4: Adjusted probabilities to buy (with 95\% CIs)

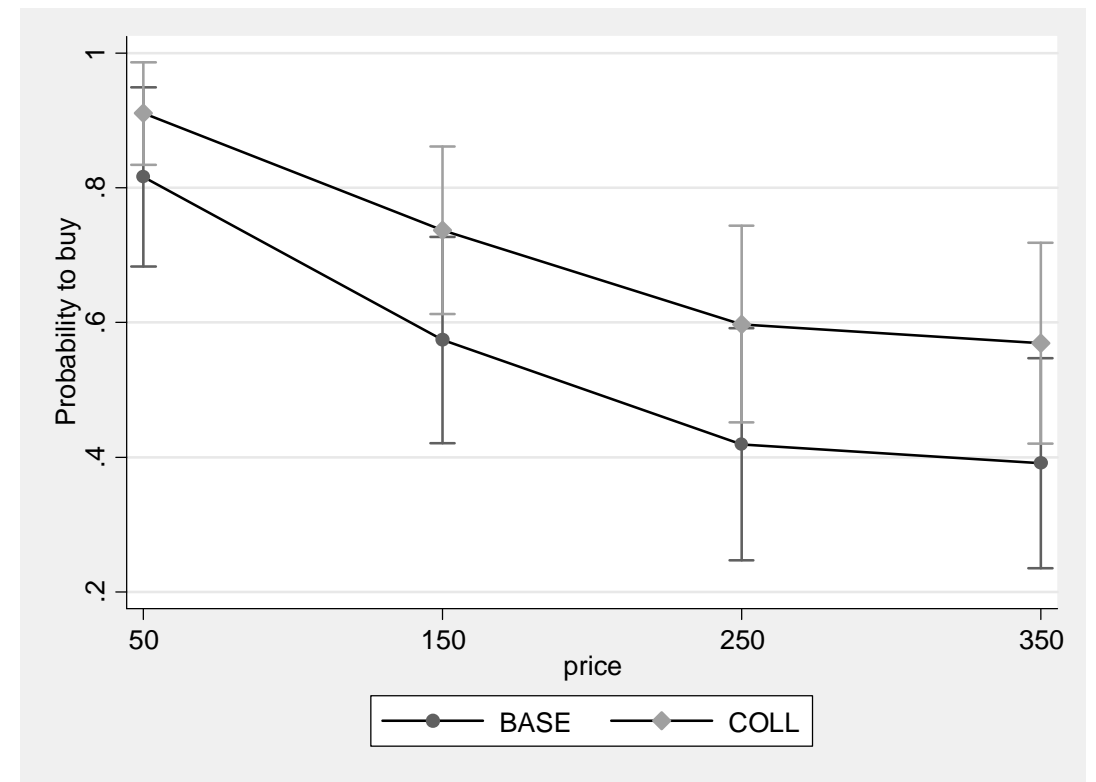

\subsection{Heckman selection model}

To estimate the effects of climate change attitudes, socioeconomics and price of the quantity bought, a simple OLS approach is not sufficient on account of the highly skewed independent variable. The literature proposes several models for this kind of data structure. Probably best known is the Tobit model, which unfortunately relies heavily on distributional assumptions. If the error term is either heteroscedastic or non-normal, coefficients and marginal effects are inconsistent (Cameron and Trivedi 2005). For the Tobit model, the dependent variable $\ln (q+1)$ is clearly non-normal and therefore Tobit coefficients will be inconsistent. Results for the Tobit specification are therefore not presented here. A more flexible way to model the demand for $\mathrm{CO}_{2}$ reduction is Heckman's two step estimator. Note that a simple OLS regression of quantity including only positive demand leads to inconsistent estimators if the decision to purchase certificates is related to the decision of how much to buy or, technically speaking, if the error terms of both separately modelled decisions are correlated. The two step estimator adds the inverse Mills ratio (IMR) from the first step probit regression to an OLS regression of positive quantities. Then it is possible to test whether or not errors are correlated using a Wald test based on the estimated coefficient of the IMR (Cameron and Trivedi 2005). Column 1 of Table 11 replicates the third model from Table 9 and column 2 shows the coefficients from a regression that includes only positive demand. Both columns compose the 
two-part model. Column 3 shows the level equations of the two-step model and column 4 shows the level equation with exclusion restrictions, which means, that independent variables were excluded in order to reduce multicollinearity.

The insignificance of the IMR in both two-step models of column 3 and 4 shows that we cannot reject the null hypothesis of correlated errors, which at least gives some indication of two independent decisions. Then the two decisions can be modelled separately and the twopart model is appropriate. This result differs from Löschel et al. (2013) and might originate in the differences in the data structure. For example here, fewer data points per individual are exploited than in Löschel et al. (2013), where five price-quantity combinations are used instead of only two. The lower number of observations could cause multicollinearity, which is a serious issue in two step estimation (Leung and $\mathrm{Yu}$ 1996). ${ }^{28}$

Column 4 gives the reduced equation for the decision of how much to buy. The most important result from the exclusion restriction is that multicollinearity is strongly reduced, however with a condition number of 46.7 still prevails. ${ }^{29}$ Significance levels and coefficient sizes are very similar to the full selection equation and to the two step model. Strikingly no climate change attributes have an effect on the decision of how much to buy, except the dummy for personal action. From the demographics, only income is related to the quantity demanded, conditional on positive demand.

\footnotetext{
28 This is because the IMR is a linear combination of the regressors of the first step equation. Investigating multicollinearity of the level equation of the two-step model shows, that the IMF has a variance inflation factor (VIF) of 13.46 and the condition number of the regression with IMF is very high (93.61). The two-part model, in contrast doesn't suffer multicollinearity as VIF values of all regressors are below ten and the condition number is below 40 .

${ }^{29}$ Leung and $\mathrm{Yu}$ (1996) show in Monte Carlo simulations that a condition number of over 20 suggests multicollinearity problems in two-step models.
} 
Table 11: Econometric models of demand behavior

\begin{tabular}{|c|c|c|c|c|}
\hline & \multicolumn{2}{|c|}{ Two-Part Model } & \multicolumn{2}{|c|}{ Selection Two-Step Model } \\
\hline & $(1)$ & $(2)$ & (3) & $(4)$ \\
\hline & $\begin{array}{l}\text { Decision } \\
\text { model } 3\end{array}$ & $\begin{array}{l}\text { Level } \\
\text { equation }\end{array}$ & $\begin{array}{l}\text { Level } \\
\text { equation }\end{array}$ & $\begin{array}{c}\text { reduced } \\
\text { level } \\
\text { equation }\end{array}$ \\
\hline & q_d & $\ln \_q_{g>0}$ & $\ln \_q_{q}>0$ & $\ln \_q_{q}>0$ \\
\hline $\ln (\mathrm{p})$ & $\begin{array}{l}-0.58^{* * * * *} \\
(0.11)\end{array}$ & $\begin{array}{l}-0.83^{* * * *} \\
(0.06)\end{array}$ & $\begin{array}{c}-0.88^{* * * *} \\
(0.15)\end{array}$ & $\begin{array}{c}-0.73^{* * * *} \\
(0.12)\end{array}$ \\
\hline \multicolumn{5}{|l|}{ Demographics } \\
\hline Single & $\begin{array}{l}-0.82^{* *} \\
(0.33)\end{array}$ & $\begin{array}{l}0.15 \\
(0.20)\end{array}$ & $\begin{array}{c}0.08 \\
(0.33)\end{array}$ & \\
\hline Female & $\begin{array}{l}-0.07 \\
(0.24)\end{array}$ & $\begin{array}{c}0.19 \\
(0.15)\end{array}$ & $\begin{array}{c}0.18 \\
(0.16)\end{array}$ & \\
\hline Age & $\begin{array}{l}-0.02^{* *} \\
(0.01)\end{array}$ & $\begin{array}{c}0.00 \\
(0.01)\end{array}$ & $\begin{array}{l}-0.00 \\
(0.01)\end{array}$ & \\
\hline Children in household (yes/no) & $\begin{array}{l}-1.07^{* * *} \\
(0.36)\end{array}$ & $\begin{array}{l}-0.52^{*} \\
(0.31)\end{array}$ & $\begin{array}{l}-0.61 \\
(0.48)\end{array}$ & \\
\hline Education (high/low) & $\begin{array}{l}-0.01 \\
(0.22)\end{array}$ & $\begin{array}{c}0.11 \\
(0.15)\end{array}$ & $\begin{array}{c}0.10 \\
(0.17)\end{array}$ & $\begin{array}{c}0.10 \\
(0.18)\end{array}$ \\
\hline Working (yes/no) & $\begin{array}{c}0.27 \\
(0.25)\end{array}$ & $\begin{array}{l}-0.19 \\
(0.16)\end{array}$ & $\begin{array}{l}-0.15 \\
(0.20)\end{array}$ & $\begin{array}{l}-0.22 \\
(0.17)\end{array}$ \\
\hline Income (7 groups) & $\begin{array}{c}0.08 \\
(0.09)\end{array}$ & $\begin{array}{l}0.13^{* *} \\
(0.06)\end{array}$ & $\begin{array}{l}0.13^{* *} \\
(0.06)\end{array}$ & $\begin{array}{l}0.10^{*} \\
(0.05)\end{array}$ \\
\hline $\begin{array}{l}\text { Member in environmental } \\
\text { organization (yes/no) }\end{array}$ & $\begin{array}{l}-0.04 \\
(0.33)\end{array}$ & $\begin{array}{c}0.25 \\
(0.24)\end{array}$ & $\begin{array}{c}0.25 \\
(0.25)\end{array}$ & $\begin{array}{c}0.33 \\
(0.25)\end{array}$ \\
\hline \multicolumn{5}{|l|}{ Opinions and attitudes } \\
\hline $\begin{array}{l}\text { Informational status about CC (4 } \\
\text { point scale) }\end{array}$ & $\begin{array}{l}0.38^{*} \\
(0.20)\end{array}$ & $\begin{array}{c}0.06 \\
(0.12)\end{array}$ & $\begin{array}{c}0.09 \\
(0.16)\end{array}$ & $\begin{array}{c}0.01 \\
(0.14)\end{array}$ \\
\hline Worried about CC ( 5 point scale) & $\begin{array}{l}0.22^{* *} \\
(0.11)\end{array}$ & $\begin{array}{l}-0.08 \\
(0.07)\end{array}$ & $\begin{array}{l}-0.06 \\
(0.10)\end{array}$ & $\begin{array}{l}-0.09 \\
(0.08)\end{array}$ \\
\hline $\begin{array}{l}\text { CC poses a serious threat to people } \\
\text { in developing countries (yes/no) }\end{array}$ & $\begin{array}{l}0.61^{* *} \\
(0.30)\end{array}$ & $\begin{array}{c}0.10 \\
(0.19)\end{array}$ & $\begin{array}{c}0.16 \\
(0.26)\end{array}$ & $\begin{array}{c}0.00 \\
(0.23)\end{array}$ \\
\hline Still need for commitment to & 0.24 & 0.20 & 0.22 & 0.21 \\
\hline tackle CC (yes/no or don't know) & $(0.33)$ & $(0.21)$ & $(0.26)$ & $(0.25)$ \\
\hline Personal behavior has influence on & -0.13 & $0.42^{* *}$ & $0.41^{* *}$ & $0.44^{* *}$ \\
\hline CC (yes/no or don't know) & $(0.24)$ & $(0.18)$ & $(0.20)$ & $(0.21)$ \\
\hline Treatment indicators & & & & 0.00 \\
\hline INFO & $\begin{array}{c}0.18 \\
(0.27)\end{array}$ & $\begin{array}{l}-0.11 \\
(0.19)\end{array}$ & $\begin{array}{l}-0.08 \\
(0.22)\end{array}$ & $\begin{array}{l}-0.12 \\
(0.19)\end{array}$ \\
\hline COLL & $\begin{array}{l}0.68^{* *} \\
(0.27)\end{array}$ & $\begin{array}{c}0.12 \\
(0.23)\end{array}$ & $\begin{array}{c}0.18 \\
(0.29)\end{array}$ & $\begin{array}{c}0.00 \\
(0.21)\end{array}$ \\
\hline Inverse Mills Ratio & & & $\begin{array}{c}0.67 \\
(1.87)\end{array}$ & $\begin{array}{l}-1.41 \\
(1.35)\end{array}$ \\
\hline Constant & $\begin{array}{l}1.91^{* *} \\
(0.96)\end{array}$ & $\begin{array}{l}4.67^{* * *} \\
(0.55)\end{array}$ & $\begin{array}{l}4.50^{* * *} \\
(0.73)\end{array}$ & $\begin{array}{l}5.34^{* * *} \\
(0.74) \\
\end{array}$ \\
\hline Condition Number & & 38.30 & 93.61 & 46.71 \\
\hline Adjusted $\mathrm{R}^{2}$ & & 0.484 & 0.481 & 0.458 \\
\hline $\mathrm{N}$ & 270 & 166 & 166 & 166 \\
\hline
\end{tabular}

By looking at the first step equation, we find a couple of determinants which are related to the decision to buy, but not to the decision on how much to buy or vice versa. For example income has no effect on the probability to buy permits, but has a positive influence on 
quantity given a positive demand. This structural influence of income has been found in other WTP studies as well (e.g. Liebe et al. 2011). The same holds for the attitude on personal behaviour. Other climate change attributes are related to the decision to buy, but do not influence the quantity that subjects choose to purchase. Whether subjects have children may negatively influence demand for $\mathrm{CO}_{2}$ reduction. It could be assumed that people with children could have stronger time and budget constraints making them less likely to contribute. The COLL treatment, which has a positive influence on the decision to buy, does not have an influence on the quantity demanded.

\subsection{Motivation to buy}

After the subjects had made their purchase, they were asked for the reasons influencing their decision (these reasons are displayed in Table 16 in Annex I, question Q2.6, given a positive amount for at least one of the two prices was stated). More than $90 \%$ of subjects replied that they purchased permits because they personally wanted to contribute to climate protection, almost $90 \%$ wanted to buy because they cared for future generations and about $70 \%$ did so, because they were concerned about people in developing countries and about the natural environment. About $45 \%$ bought permits, because they thought that the government was not doing enough against climate change, however almost 36\% were not sure about this point thereby indicating a high level of uncertainty with regard to the government's contribution. Expectations from friends and acquaintances as well as from the organisers were a reason to buy for less than $10 \%$ of the sample.

Subjects who did not buy permits at any of the prices (36.5\%) were also asked to give reasons for this non-purchase (Table 17 in Annex I, question Q2.7). Almost 70\% agreed that their purchase would not actually reduce emissions in Europe. About 48\% said that the market for permits did not work and that restrictions and environmental provisions were better instruments to mitigate climate change. About $36 \%$ agreed with the statement that emission trading suited the interest of large scale industry only, while only $17 \%$ refused to comment on their position. The responses show some general distrust in the emissions trading system per se. Only a minority of $36 \%$ thought that emissions could be measured and controlled. This reveals a lack of crucial technical background knowledge on the part of the majority of this non-purchasing group. Distrust in the ZEW was no reason to abstain from buying permits for any participant.

Subjects are undecided regarding the effect of international collaboration on personal demand (Table 17 in Annex I, question Q2.8). About half of the participants indicated that their 
demand would have remained unchanged if other industrialised countries had agreed to reduce their emissions whilst about $40 \%$ of the sample stated that they would have increased their demand. The same divided opinion of demand occurs if emerging countries agree to reduce emissions, whereas if developing countries agree on mitigation of emissions, only $22 \%$ would have had higher demand and $61 \%$ would have remained unchanged. This demonstrates that at least some degree of conditional cooperative behaviour among our subjects exists and the participation of developing countries is much less crucial for the support of emission reduction schemes than is the participation of industrialised and emerging countries, especially China.

\section{Discussion and conclusion}

In this paper, we confronted subjects with a real decision making situation in which they could contribute to climate protection. We complement previous studies by introducing some form of collective action into a revealed preference study which moderates the free rider option existing in this approach. Free riding is, of course, the underlying problem in the realworld efforts to mitigate climate change. It has not, however, been considered in revealed preference studies on climate protection thus far and is usually excluded in stated preference studies where collective provision of climate protection at a specific level is assumed.

Our paper has shed light on the extent and the underlying factors of the real demand for climate protection, when the purely individual perspective of existing revealed preference studies is relaxed. For this purpose, subjects were given the opportunity to buy EUAs at a given price under different conditions. In one subgroup, subjects received information about the observed behaviour of another group under a similar decision making situation. Subjects in a second subgroup were asked to state their demand under a collective action rule where all subjects were required to purchase the median quantity at a given price.

The mean (median) WTP for climate protection for our subject pool is low and amounts to $11 € / \mathrm{tCO}_{2}\left(5 € / \mathrm{tCO}_{2}\right)$. The existence of information about the behaviour of other subjects who also had the opportunity to contribute to the global public good has no effect on the average demand. One may interpret this result as evidence for a rather stable WTP and that some subjects contribute to climate protection irrespectively of what others do. The introduction of a collective action in small groups of about 30 subjects increases the probability to contribute to climate protection compared to the individual contribution mechanism where complete free riding is possible. The WTP under this collective action rule, however, is only slightly higher $\left(13.3 € / \mathrm{tCO}_{2}\right)$ than in a scenario where free riding is possible $\left(9.1 € / \mathrm{tCO}_{2}\right)$. 
Further to this treatment effect, we also observed that individual contributions to climate protection are positively correlated with expectations about the others' demand. Thus, reciprocal behaviour seems to affect the contribution decision. Subjects with higher expectations regarding others' contributions show a stronger demand for climate protection. On average, however, subjects behave consistently with free rider behaviour. Positive contributions by others are anticipated, and the personal contribution is below the expectations regarding others' contributions. Only by means of a collective action can this free riding be partly avoided if the price of contribution is sufficiently small.

Our results have importance also from a methodological point of view. On the one hand, the mechanism used in this paper for the elicitation of the demand for climate protection avoids the hypothetical bias frequently observed in stated preference studies (see, Murphy et al. 2005, for example). This advantage, however, is accompanied with a significant drawback in that it seems impossible to implement the appropriate "real" collective action frame. In companion with other studies, such as Menges and Traub (2009), this experiment has demonstrated that the demand for public goods depends upon the implemented collective action or inaction frame. Hence, we are still some distance away from claiming that our approach gives the "true" demand or WTP for climate protection. It can easily be imagined that in a frame where subjects would be ensured that action on climate change is taken at the national or even at the global level, demand for climate protection would be higher. That said, it should be kept in mind that free riding on other subject's contribution is an important observation in climate protection. In addition, even under an international agreement, noncompliance would be possible, and this, it seems, is a widespread phenomenon. In any case, these conditions can hardly be implemented in an experiment. Thus, stated preferences surveys will be needed as a complementary approach to explore the links between the degrees of participation in mitigating climate change and individual WTP.

Two experimental research strategies may help to further investigate this issue. First, appropriately designed field experiments (see Harrison and List 2004) could help to shed light on the "true" real WTP. For reliable WTP estimates, however, such field experiments have to find a way to control subjects' $\mathrm{CO}_{2}$ related behaviour in large groups, for example, by controlling electricity consumption or driving behaviour. Second, one could use large scale laboratory experiments. Weimann et al. (2012) recently reported standard public good experiments with large groups $(\mathrm{N}=60$ and $\mathrm{N}=100)$. In a similar setting one could explore the extent to which the WTP depends on the implemented collective action, and in particular, the number of subjects involved. 


\section{References}

Achtnicht, M. (2012), German Car Buyers' Willingness to Pay to Reduce $\mathrm{CO}_{2}$ Emissions, Climatic Change 113(3), 679-697.

Blasch, J. and M. Farsi (2012), Retail demand for voluntary carbon - a choice experiment among Swiss consumers, ETH Zurich, University of Neuchatel, discussion paper, http://mpra.ub.uni-muenchen.de/41259/.

Brouwer R., L. Brander, and P. Van Beukering (2008), "A convenient truth": air travel passengers willingness to pay to offset their $\mathrm{CO}_{2}$ emissions, Climatic Change 90(3), 299-313.

Carson, R., T. Groves, and J. List (2006), Probabilistic Influence and Supplemental Benefits. A Field Test of the Two Key Assumptions Behind Using Stated Preferences, Discussion Paper, September 2006.

Cameron, A.C. and P.K. Trivedi (2005), Microeconometrics. Methods and Applications. Cambridge, New York: Cambridge University Press.

Cameron, A. Colin.,J.B. Gelbach, and D.L. Miller (2008), Bootstrap-Based Improvements for Inference with Clustered Errors, Review of Economics and Statistics 90(3), 414-427.

Carlsson, F., M. Kataria, A. Krupnick, E. Lampi, A. Lofgren, P. Qin, S. Chung, and T. Sterner (2012), Paying for Mitigation. A Multiple Country Study, Land Economics 88(2), 326-340.

Carlsson, F, M., D. Daravula, and H. Jaldell (2010), Do you do what you say or do you do what you say others do? Journal of Choice Modelling 3(2), 113-133.

Champ, P.A., R.C. Bishop, T.C. Brown, and D.W. McCollum (1997), Using Donation Mechanisms to Value Nonuse Benefits from Public Goods, Journal of Environmental Economics and Management 33(2), 151-162.

Champ, P.A., N.E. Flores, T.C. Brown, and J. Chivers (2002), Contingent Valuation and Incentives, Land Economics 78(4), 591-604.

Cherry, T.L. (2001), Mental accounting and other-regarding behaviour: Evidence from the lab, Journal of Economic Psychology 22(5), 605-615.

Cherry, T.L., P. Frykblom, and J.F. Shogren (2002), Hardnose the Dictator, American Economic Review 92(4), 1218-1221.

Cummings, R.G., S. Elliott, G.W. Harrison, and J. Murphy (1997), Are Hypothetical Referenda Incentive Compatible? Journal of Political Economy 105(3), 609-621.

Diederich, J. and T. Goeschl (2011), Willingness to Pay for Individual Greenhouse Gas Emissions Reductions: Evidence from a Large Field Experiment, Discussion Paper Series No. 517, Department of Economics, University of Heidelberg, Heidelberg, September 2011.

Fischbacher, U., S. Gächter, and E. Fehr (2001), Are People Conditionally Cooperative? Evidence from a Public Goods Experiment, Economics Letters 71, 397-404.

Frey, B. and S. Meier (2004), Social Comparisons and Pro-Social Behavior: Testing "Conditional Cooperation" in a Field Experiment, American Economic Review 94(5), 1717-1722.

Harrison, G.W. and J.A. List (2004), Field Experiments, Journal of Economic Literature 42(4), 1009-1055.

Hersch, J. and K.W. Viscusi (2006), The Generational Divide in Support for Environmental Policies: European Evidence, Climatic Change 77(1/2), 121-136.

Johansson-Stenman, O. and H. Svedsäter (2010), Self-Image and Valuation of Moral Goods: Stated versus Actual Willingness to Pay, Journal of Economic Behavior and Organization 84(3), 879-891.

Johnson, E. and G.F. Nemet (2010), Willingness to pay for climate policy: a review of estimates, Working Paper Series, La Follette School Working Paper No. 2010-011.

Kahneman, D. and J.L. Knetsch (1992), Valuing public goods: The purchase of moral satisfaction, Journal of Environmental Economics and Management 22(1) 57-70.

Leung, S. F. and S. Yu (1996), On the choice between sample selection and two-part models, Journal of Econometrics 72 (1-2), 197-229,

Liebe, U., P. Preisendörfer, and J. Meyerhoff (2011), To Pay or Not to Pay: Competing Theories to Explain Individuals' Willingness to Pay for Public Environmental Goods, Environment and Behavior, 43(1), 106-130. 
Löschel, A., B. Sturm, and C. Vogt (2013), The Demand for Climate Protection - An Empirical Assessment for Germany, forthcoming in Economics Letters.

Lusk, J. and B. Norwood (2009a), An inferred valuation method. Land Economics 85(3), 500-514.

Lusk, J. and B. Norwood (2009b), Bridging the gap between laboratory experiments and naturally occurring markets: An inferred valuation method, Journal of Environmental Economics and Management 58(2), 236-250.

MacKerron, G.J., C. Egerton, C. Gaskell, A. Parpia, and S. Mourato (2009), Willingness to pay for carbon offset certification and co-benefits among (high-)flying young adults in UK, Energy Policy 37(4), 1372-1381.

Menges, R. and S. Traub (2009), An Experimental Study on the Gap between Willingness to Pay and Willingness to Donate for Green Electricity, Finanzarchiv/Public Finance Analysis 65(3), 335-357.

Murphy, J.J., P.G. Allen, T.H. Stevens, and D. Weatherhead (2005), A Meta-Analysis of Hypothetical Bias in Stated Preference Valuation, Environmental and Resource Economics 30(3), 313-325.

Newson, R. (2002), Parameters behind "nonparametric" statistics: Kendall's tau, Somers' D and median differences, Stata Journal 2(1), 45-64.

Newson, R. (2006), Confidence intervals for rank statistics: Somers' D and extensions, Stata Journal6 (3), 309-334.

Riedl, A. (2011), Experimental Economics. Economic and Game Theoretic Principles in Experimental Research in the Social Sciences, Netspar Discussion Papers 12/2011-109.

Roberts, R.D. (1984), A positive model of private charity and public transfers, Journal of Political Economy92(1), 136-148.

StaLa BWL (2007), Struktur- und Regionaldatenbank, http://www.statistik.badenwuerttemberg.de/, November 2007.

Sturm, B. and J. Weimann (2006), Experiments in Environmental Economics and some Close Relatives, Journal of Economic Surveys 20(3), 419-457

Spash, C.L. (2000), Ecosystems, contingent valuation and ethics: the case of wetland re-creation, Ecological Economics 34(2), 195-215.

Spash, C. L. (2006), Non-Economic Motivation for Contingent Values: Rights and Attitudinal Beliefs in the Willingness To Pay for Environmental Improvements, Land Economics 82(4), 602-622.

Sugden, R. (1984), Reciprocity: The Supply of Public Goods through Voluntary Contributions, Economic Journal 94(376), 772-787.

Taylor, L.O. (1998), Incentive Compatible Referenda and the Valuation of Environmental Goods, Agriculture and Resource Economics Review 27(2), 132-139.

Taylor, L.O., M. McKee, S.K. Laury, and R.G. Cummings (2001), Induced-value tests of the referendum voting mechanism, Economic Letters 71(1), 61-65.

Viscusi W.K. and R. Zeckhauser (2006), The reception and valuation of the risks of climate change: A rational and behavioral blend, Climate Change 77, 141-177.

Warr, P.G. (1982), Pareto optimal redistribution and private charity, Journal of Public Economics 19(1), 131-138.

Weimann, J., J. Brosig-Koch, H. Henning-Schmidt, and C. Keser (2012), Public-good experiments with large groups, working paper, University of Magdeburg.

Wiser, R. (2007), Using Contingent Valuation to Explore Willingness to Pay for Renewable Energy: A Comparison of Collective and Voluntary Payment Vehicles, Ecological Economics 62(3/4), 419-432.

Wooldridge, J. M. (2009), Introductory econometrics. A modern approach. 4. Edition. SouthWestern Cengage Learning. 


\section{Annex I: Descriptive statistics of questionnaires}

Table 12: Socio-economic characteristics of participants - part I

Q1.1 Please state your marital status

\begin{tabular}{lr}
\hline answer & in \% \\
\hline married & 30.6 \\
unmarried with partner & 10.8 \\
single & 54.1 \\
other & 4.5 \\
\hline
\end{tabular}

Q1.2 Please state your sex

\begin{tabular}{lr}
\hline answer & in \% \\
\hline female & 49.0 \\
male & 50.3 \\
NA & 0.6 \\
\hline
\end{tabular}

Q1.3 Please state your age

\begin{tabular}{lrrr}
\hline age group & total in $\%$ & female in $\%$ & male in $\%$ \\
\hline$(18,25]$ & 18.5 & 23.8 & 12.8 \\
$(25,35]$ & 28.0 & 30.0 & 25.6 \\
$(35,45]$ & 15.9 & 12.5 & 19.2 \\
$(45,55]$ & 12.1 & 13.8 & 10.3 \\
$(55,65]$ & 9.6 & 7.5 & 11.5 \\
$(65,75]$ & 14.0 & 8.8 & 18.0 \\
NA & 1.9 & 3.8 & 2.6 \\
\hline
\end{tabular}

Q1.4 Are you a member of a religious community?

\begin{tabular}{lr}
\hline answer & in \% \\
\hline no & 45.2 \\
yes & 54.1 \\
NA & 0.6 \\
\hline
\end{tabular}

Q1.5 How many children live in your household?

\begin{tabular}{lr}
\hline answer & in $\%$ \\
\hline 0 & 83.4 \\
1 & 8.3 \\
2 & 7.0 \\
3 or more & 1.3 \\
\hline
\end{tabular}

Q1.6 Please state the institution at which you have acquired your highest professional degree

\begin{tabular}{lr}
\hline answer & in \% \\
\hline No school-leaving qualifications & 0.6 \\
Secondary school without professional qualification & 8.3 \\
Entrance requirement for higher education without professional qualification & 14.0 \\
Completion of an apprenticeship & 14.7 \\
Entrance requirement for higher education and completion of an apprenticeship & 19.8 \\
Degree & 39.5 \\
Promotion & 2.6 \\
Other & 0.6 \\
\hline
\end{tabular}

Q1.7 Please state your nationality of origin

\begin{tabular}{lr}
\hline answer & in \% \\
\hline German & 83.4 \\
Turkish & 3.2 \\
Russian & 2.6 \\
Italian & 1.9 \\
Other & 8.9 \\
\hline
\end{tabular}


Table 13: Socio-economic characteristics of participants - part II

Q1.8 How much money is available in your household per month (net income)?

\begin{tabular}{lr}
\hline answer & in \% \\
\hline$[0 €, 500 €)$ & 8.3 \\
{$[500 €, 1000 €)$} & 20.4 \\
{$[1000 €, 1500 €)$} & 17.2 \\
{$[1500 €, 2000 €)$} & 15.9 \\
{$[2000 €, 3000 €)$} & 15.9 \\
{$[3000 €, 4000 €)$} & 7.6 \\
{$[4000 €$ and more $)$} & 8.3 \\
NA & 6.4 \\
\hline
\end{tabular}

Q1.9 If Sunday were Election Day, which party would you vote for?

\begin{tabular}{lr}
\hline answer & in \% \\
\hline CDU/CSU - Christian Democratic Union/Christian Social Union & 24.8 \\
SPD - Social Democratic Party & 14.7 \\
Alliance 90/ The Greens & 26.8 \\
FDP - Free Liberal Party & 3.2 \\
Die Linke - The Left & 3.2 \\
Other & 3.2 \\
I do not vote & 9.6 \\
NA & 14.7 \\
\hline
\end{tabular}

Q1.10 What's your profession?

\begin{tabular}{lr}
\hline answer & in \% \\
\hline Employee & 33.1 \\
Worker & 3.8 \\
Public official/Civil cervant & 0.6 \\
Self-employed & 7.6 \\
Seeking employment/unemployed & 5.7 \\
Pupil & 0.6 \\
Student & 24.2 \\
Retiree & 19.8 \\
Other & 4.5 \\
\hline
\end{tabular}

Q1.11 Are you a member of an initiative or organisation promoting environmental protection?

\begin{tabular}{lr}
\hline answer & in \% \\
\hline no & 86.0 \\
yes & 12.7 \\
NA & 1.3 \\
\hline
\end{tabular}

Q1.12 Please rate your level of information regarding climate change. I am...

\begin{tabular}{lr}
\hline answer & in \% \\
\hline Rather poorly informed & 8.3 \\
Reasonably well informed & 58.6 \\
Rather well informed & 28.0 \\
Very well informed & 4.5 \\
NA & 0.6 \\
\hline
\end{tabular}

Q1.13 Are you concerned about climate change?

\begin{tabular}{lr}
\hline answer & in \% \\
\hline Not at all concerned & 1.3 \\
Rather not concerned & 11.5 \\
Neutral & 21.0 \\
Rather concerned & 47.8 \\
Very concerned & 17.8 \\
NA & 0.6 \\
\hline
\end{tabular}


Table 14: Questionnaire 1 - part III

Q1.14 Do you expect noticeable negative consequences of climate change for your personal life?

\begin{tabular}{lr}
\hline answer & in \% \\
\hline no & 46.5 \\
yes & 52.2 \\
no answer & 1.3 \\
\hline
\end{tabular}

Q1.15 Do you expect noticeable positive consequences of climate change for your personal life?

\begin{tabular}{lr}
\hline answer & in \% \\
\hline no & 86.0 \\
yes & 10.8 \\
no answer & 3.2 \\
\hline
\end{tabular}

Q1.16 To what extent do you think that climate change poses a serious threat to the respective areas?

\begin{tabular}{lrrrr}
\hline Area $\downarrow$ & $\begin{array}{r}\text { No serious } \\
\text { threat in \% }\end{array}$ & $\begin{array}{r}\text { Don't know / } \\
\text { neutral in \% }\end{array}$ & $\begin{array}{r}\text { Serious } \\
\text { threat in \% }\end{array}$ & NA in \% \\
\hline a) For me and my family & 43.3 & 37.6 & 17.2 & 1.9 \\
b) For my children (if applicable) & 11.5 & 58.0 & 24.8 & 5.7 \\
c) Future generations in general & 3.2 & 17.2 & 79.6 & 0.0 \\
d) Friends, acquaintances, colleagues & 32.5 & 45.2 & 19.1 & 3.2 \\
e) People in Germany in general & 32.5 & 36.3 & 28.7 & 2.6 \\
f) People in other industrialized countries & 19.8 & 33.8 & 44.0 & 2.6 \\
g) People in developing countries & 4.5 & 16.6 & 75.8 & 3.2 \\
\hline
\end{tabular}

Q1.17 When do you expect the impacts of climate change to become visible?

\begin{tabular}{lr}
\hline answer & in \% \\
\hline never & 1.3 \\
in more than 100 years & 2.6 \\
within the next 100 years & 12.1 \\
within the next 50 years & 23.6 \\
within the next 10 years & 14.0 \\
already visible & 43.9 \\
NA & 2.6 \\
\hline
\end{tabular}

Q1.18 Do you think that there still is a need for commitment to tackle climate change?

\begin{tabular}{lr}
\hline answer & in \% \\
\hline no & 9.6 \\
yes & 86.0 \\
don't know & 4.5 \\
\hline
\end{tabular}

Q1.19 To what extent do you agree to the following statements?

\begin{tabular}{|c|c|c|c|c|}
\hline Statement $\downarrow$ & $\begin{array}{r}\text { Do not agree } \\
\text { in \% }\end{array}$ & $\begin{array}{l}\text { Don't know/ } \\
\text { neutral in \% }\end{array}$ & $\begin{array}{r}\text { Agree in } \\
\% \\
\end{array}$ & NA in $\%$ \\
\hline $\begin{array}{l}\text { a) I believe my personal behaviour has } \\
\text { influence on climate change. }\end{array}$ & 14.7 & 17.8 & 67.5 & 0.0 \\
\hline $\begin{array}{l}\text { b) My behaviour to avoid climate change can } \\
\text { encourage others in my environment to behave } \\
\text { the same way. }\end{array}$ & 8.9 & 21.0 & 68.8 & 1.3 \\
\hline $\begin{array}{l}\text { c) The government is solely responsible for } \\
\text { measures against climate change. }\end{array}$ & 81.5 & 12.7 & 3.8 & 1.9 \\
\hline
\end{tabular}


Table 15: Questionnaire 2 - part I

Q2.1 Please answer the following questions concerning your expectations of the other participants' behaviour (for results see Table 4 in the paper)

\begin{tabular}{|l|l|}
\hline $\begin{array}{l}\text { How much do you think did the majority of participants demand at the price }=€ 2.50 ? \\
\text { In other words: What is the median quantity at the price }=€ 2.50 ?\end{array}$ & Median quantity \\
\hline & \\
\hline How much do you think did the majority of participants at least demand at the price $=$ & \\
$€ 0.50$ ? In other words: What is the median quantity at the price $=€ 0.50$ ? & ---------- \\
\hline
\end{tabular}

Example for 5 participants who state a quantity to a respective price:

Quantities $=0,0,1,4,10$. Median $=1$, i.e., the majority of participants demanded at least 1 unit at this price.

\begin{tabular}{|l|l|}
\hline & Average quantity \\
\hline $\begin{array}{l}\text { How much do you think did the participants demand at the price }=€ 2.50 \text { on average? } \\
\text { In other words: What is the average quantity at the price }=€ 2.50 ?\end{array}$ & \\
\hline & -------------- \\
\hline $\begin{array}{l}\text { How much do you think did the participants demand at the price }=€ 0.50 \text { on average? } \\
\text { In other words: What is the average quantity at the price }=€ 0.50 ?\end{array}$ & \\
\hline
\end{tabular}

Example for 5 participants who state a quantity to a respective price:

Quantities: $0,0,1,4,10$. Average $=15 / 5=3$

Q2.2 Please answer the following questions concerning your behaviour

\begin{tabular}{|c|c|c|c|c|c|}
\hline $\begin{array}{l}\text { How would your demand (for both prices) } \\
\text { have turned out if, }\end{array}$ & $\begin{array}{r}\text { Greater } \\
\text { in } \%\end{array}$ & $\begin{array}{r}\text { Unchanged } \\
\text { in } \% \\
\end{array}$ & $\begin{array}{r}\text { Lower } \\
\text { in \% }\end{array}$ & $\begin{array}{r}\text { Don't } \\
\text { know in \% }\end{array}$ & $\begin{array}{r}\text { NA in } \\
\%\end{array}$ \\
\hline $\begin{array}{l}\text { a) other important industrialized countries like } \\
\text { the USA would have agreed on the mitigation } \\
\text { of their own emissions within the framework } \\
\text { of an international treaty for the protection of } \\
\text { the global climate. }\end{array}$ & 41.4 & 49.0 & 3.8 & 5.1 & 0.6 \\
\hline $\begin{array}{l}\text { b) important emerging countries like the } \\
\text { People's Republic of China would have agreed } \\
\text { on the mitigation of their own emissions } \\
\text { within the framework of an international treaty } \\
\text { for the protection of the global climate. }\end{array}$ & 45.2 & 44.0 & 4.5 & 5.7 & 0.6 \\
\hline $\begin{array}{l}\text { c) developing countries would have agreed on } \\
\text { the mitigation of their own emissions within } \\
\text { the framework of an international treaty for the } \\
\text { protection of the global climate. }\end{array}$ & 21.7 & 60.5 & 4.5 & 12.7 & 0.6 \\
\hline
\end{tabular}

Q2.3 Emission allowances of the European Emissions Trading System (certificates) are traded on the stock exchange. How would you estimate the price of such a certificate on the stock exchange?

$100 \mathrm{~kg}$ of $\mathrm{CO}_{2} \operatorname{cost} €$

\begin{tabular}{lr}
\hline price interval & in \% \\
\hline$(0,10]$ & 4.5 \\
$(10,20]$ & 0.6 \\
$(20,30]$ & 1.9 \\
$(30,100]$ & 17.2 \\
$(100,1000]$ & 30.6 \\
$(1000,10000]$ & 26.8 \\
more than 10000 & 13.4 \\
NA & 5.1 \\
\hline
\end{tabular}


Table 16: Questionnaire 2 - part II

Q2.4 How sure are you about your estimation of the question above?

\begin{tabular}{lr}
\hline answer & in \% \\
\hline sure & 0.6 \\
rather sure & 3.2 \\
unsure & 31.2 \\
I don't know/guessed & 63.1 \\
no answer & 1.9 \\
\hline
\end{tabular}

Q2.5 Will you talk about this event and your behaviour in it with your family, your friends or your colleagues?

\begin{tabular}{lr}
\hline answer & in \% \\
\hline no & 4.5 \\
yes & 84.1 \\
I don't know & 10.8 \\
no answer & 0.6 \\
\hline
\end{tabular}

Q2.6 Please answer the following questions only if you want to buy certificates. That means if you have stated a positive quantity $(>0)$ at any of the prices in the auction of the certificates.

\begin{tabular}{|c|c|c|c|c|}
\hline $\begin{array}{l}\text { I want to buy permits, because... } \\
\text { Reason } \downarrow\end{array}$ & $\begin{array}{c}\text { Not } \\
\text { applicable }\end{array}$ & $\begin{array}{c}\text { I don't know/ } \\
\text { neutral }\end{array}$ & Applicable & NA \\
\hline $\begin{array}{l}\text { a) ... I want to contribute to climate protection - } \\
\text { regardless of what others do. }\end{array}$ & $4.4 \%$ & $5.2 \%$ & $90.4 \%$ & $0.0 \%$ \\
\hline $\begin{array}{l}\text { b) ... I think that others also contribute to climate } \\
\text { protection. }\end{array}$ & $13.9 \%$ & $27.0 \%$ & $55.7 \%$ & $3.5 \%$ \\
\hline $\begin{array}{l}\text { c) ... especially people in poor countries will suffer } \\
\text { the consequences of } \mathrm{CC} \text { and I want to do something } \\
\text { against it. }\end{array}$ & $10.4 \%$ & $19.1 \%$ & $67.8 \%$ & $2.6 \%$ \\
\hline $\begin{array}{l}\text { d) ... the industrialised countries, among them } \\
\text { Germany, have played a decisive role in causing CC. }\end{array}$ & $18.3 \%$ & $24.4 \%$ & $53.9 \%$ & $3.5 \%$ \\
\hline $\begin{array}{l}\text { e) ... future generations will suffer the consequences } \\
\text { of CC and I want to do something against it. }\end{array}$ & $3.5 \%$ & $8.7 \%$ & $87.0 \%$ & $0.9 \%$ \\
\hline f) ... the flora and fauna will suffer the consequences. & $6.1 \%$ & $16.5 \%$ & $74.8 \%$ & $2.6 \%$ \\
\hline h) $\ldots$ the government is not doing enough against CC. & $16.5 \%$ & $35.7 \%$ & $45.2 \%$ & $2.6 \%$ \\
\hline $\begin{array}{l}\text { i) ... my environment (family, friends, colleagues) } \\
\text { expects me to. }\end{array}$ & $63.5 \%$ & $21.7 \%$ & $8.7 \%$ & $6.1 \%$ \\
\hline j) ... the organisers of this event expect me to. & $73.0 \%$ & $15.7 \%$ & $6.1 \%$ & $5.2 \%$ \\
\hline $\mathrm{k}) \ldots$ it is my moral obligation. & $12.2 \%$ & $24.4 \%$ & $58.3 \%$ & $5.2 \%$ \\
\hline 1) ... it is important to protect the creation. & $13.0 \%$ & $29.6 \%$ & $53.9 \%$ & $3.5 \%$ \\
\hline
\end{tabular}

Notes: $\mathrm{N}=115$. $\mathrm{CC}-$ climate change. 
Table 17: Questionnaire 2 - part III

Q2.7 Please answer the following questions only if you have stated zero (quantity $=0$ ) at both prices for the certificates

\begin{tabular}{|c|c|c|c|c|}
\hline $\begin{array}{l}\text { I do NOT want to buy permits, because... } \\
\text { Reason } \downarrow\end{array}$ & $\begin{array}{c}\text { Not } \\
\text { applicable }\end{array}$ & $\begin{array}{c}\text { I don't know/ } \\
\text { neutral }\end{array}$ & Applicable & NA \\
\hline $\begin{array}{l}\text { a) ... I do not think that my buying of certificates } \\
\text { will actually reduce emissions in Europe. }\end{array}$ & $14.3 \%$ & $11.9 \%$ & $69.1 \%$ & $4.8 \%$ \\
\hline $\begin{array}{l}\text { b) ... a market for certificates does not work. We } \\
\text { need official prohibitions and commands. }\end{array}$ & $11.9 \%$ & $35.7 \%$ & $47.6 \%$ & $4.8 \%$ \\
\hline c) ... I already act in a climate conscious way. & $4.8 \%$ & $33.3 \%$ & $57.1 \%$ & $4.8 \%$ \\
\hline $\begin{array}{l}\text { d) ... emission trading anyhow suits the interests of } \\
\text { the large scale industry only. }\end{array}$ & $16.7 \%$ & $40.5 \%$ & $35.7 \%$ & $7.1 \%$ \\
\hline $\begin{array}{l}\text { e) ... I think that emission trading is principally } \\
\text { unethical. }\end{array}$ & $47.6 \%$ & $28.6 \%$ & $16.7 \%$ & $7.1 \%$ \\
\hline $\begin{array}{l}\text { f) ... I would buy certificates from companies which } \\
\text { have received them for free and by that subsidise } \\
\text { them. }\end{array}$ & $19.1 \%$ & $47.6 \%$ & $28.6 \%$ & $4.8 \%$ \\
\hline g) ... I do not trust ZEW. & $81.0 \%$ & $14.3 \%$ & $0.0 \%$ & $4.8 \%$ \\
\hline $\begin{array}{l}\text { h) ... I do not think that emissions can actually be } \\
\text { measured and controlled. }\end{array}$ & $35.7 \%$ & $31.0 \%$ & $28.6 \%$ & $4.8 \%$ \\
\hline
\end{tabular}

Notes: $\mathrm{N}=42$

Q2.8 To what extent do you agree to the following statements?

\begin{tabular}{|c|c|c|c|c|}
\hline Statement $\downarrow$ & $\begin{array}{r}\text { Do not } \\
\text { agree in \% }\end{array}$ & $\begin{array}{l}\text { I don't know } \\
\text { / neutral in \% }\end{array}$ & $\begin{array}{r}\text { Agree } \\
\text { in } \%\end{array}$ & $\begin{array}{l}\text { NA } \\
\text { in } \%\end{array}$ \\
\hline a) The temperature has not increased globally. & 72.0 & 8.9 & 16.6 & 2.6 \\
\hline b) Humans affected the temperature increase. & 5.7 & 12.7 & 79.6 & 1.9 \\
\hline c) We cannot do anything to stop CC. & 70.1 & 20.4 & 7.6 & 1.9 \\
\hline d) We can mitigate, but not stop CC. & 8.3 & 12.7 & 77.1 & 1.9 \\
\hline e) We can stop CC. & 55.4 & 31.9 & 8.3 & 4.5 \\
\hline $\begin{array}{l}\text { f) Germany should reduce carbon emissions, even } \\
\text { if other countries do not reduce their carbon } \\
\text { emissions. }\end{array}$ & 9.6 & 19.8 & 68.2 & 2.6 \\
\hline $\begin{array}{l}\text { g) Germany should primarily use public funding } \\
\text { to reduce carbon emissions wherever it is } \\
\text { cheapest, even if it means in another country. }\end{array}$ & 17.8 & 31.9 & 47.1 & 3.2 \\
\hline $\begin{array}{l}\text { h) Germany should primarily use public funding } \\
\text { to reduce carbon emissions in Germany. }\end{array}$ & 22.9 & 28.7 & 46.5 & 1.9 \\
\hline $\begin{array}{l}\text { i) Countries in the world should deal with } \mathrm{CC} \\
\text { primarily by reducing carbon emissions. }\end{array}$ & 10.2 & 28.0 & 59.2 & 2.6 \\
\hline $\begin{array}{l}\text { j) Countries in the world should deal with } \mathrm{CC} \\
\text { primarily by adaptation. }\end{array}$ & 34.4 & 31.2 & 31.2 & 3.2 \\
\hline $\begin{array}{l}\text { k) The information given in the survey regarding } \\
\mathrm{CC} \text { is trustworthy. }\end{array}$ & 5.7 & 16.6 & 75.2 & 2.6 \\
\hline $\begin{array}{l}\text { 1) We should prioritise environmental } \\
\text { improvements, even if we lose jobs. }\end{array}$ & 22.3 & 38.9 & 36.3 & 2.6 \\
\hline
\end{tabular}

Notes: CC - climate change. 


\section{Annex II: Instructions (treatment BASE)}

\section{General Information}

Today, we will offer you a certain product to purchase. In a few minutes you will learn which product it is and how the sale will be conducted.

As we want to assess how many units of the product you want to purchase, we would like to ask you not to talk to the other participants.

If you have any questions please do not hesitate to contact us.

\section{Rules of purchase}

Today, we will offer you a certain product to purchase. No one except for the ZEW team will learn about your statements from the event.

The process of sale can be explained in three steps:

Introduction of the product

Before we ask you to make a purchase offer we will briefly introduce the product to you.

Quantity you want to buy with different prices

You will receive a list with two prices for one unit of the product. You can state the quantity you want to purchase at the respective price. You can also state the quantity zero if you do not wish to purchase anything (there is no obligation to buy). At the end of the event we will draw one of the prices by lot. You will then buy the chosen quantity at the drawn price.

Payment

After leaving the room you will buy the chosen quantity at the drawn price. Please note: If you purchase the product, you will have to use your own money (but: your expenditures cannot exceed $€ 25$ ).

In a moment, we will go over a quick example with you.

Please note:

With these rules of purchase it is in your own interest to state only the quantity you actually want to buy at the respective prices. Please state only truthful information. 


\section{Comprehension Test}

We will now carry out a short test to check if you have fully understood the rules of purchase. Please let us know, when you have finished answering all questions (fill in the blanks or tick the box next to the question) and we will come to you.

Please take a look at the statements in the following table. A participant has stated the number of units he wants to buy for two possible prices per unit of the product if the respective price is drawn.

Please note:

The maximum expenditures for each price are $€ 25$ in this example.

\begin{tabular}{|l|l|l|l|l|}
\hline No. & $\begin{array}{l}\text { Price per } \\
\text { Unit }\end{array}$ & $\begin{array}{l}\text { How many units do I want to } \\
\text { buy at this price? }\end{array}$ & $\begin{array}{l}\text { How many units can I buy } \\
\text { in total at this price? }\end{array}$ & $\begin{array}{l}\text { Expenditures } \\
\text { Price } x \text { Units }\end{array}$ \\
\hline 1 & $€ 5.00$ & 0 & 5 & 0.00 euros \\
\hline 2 & $€ 1.00$ & 4 & 25 & 4.00 euros \\
\hline
\end{tabular}

Question: How many units will the participant buy if price no. 2 (€ 1.00) is drawn? Units

Question: How many units will the participant buy if price no. 1 is drawn (€ 5.00)? Units

What do I have to do, if I do not want to purchase the product at a certain price?

a) I state any quantity and hope that this price is not drawn. O

b) I state the quantity zero.

$\mathrm{O}$

What do I have to do if I want to buy exactly three units of the product at a certain price?
a) I state more than three units at this price.
$\mathrm{O}$
b) I state less than three units at this price.
$\mathrm{O}$
c) I state three units at this price.
$\mathrm{O}$

Assume that there are 5 participants who all state their purchase offers (quantities) at a certain price.

The quantities are as follows $0,1,3,4,12$

What is the median quantity?

Answer

What is the average quantity per participant?

Answer 


\section{Information on Climate Change}

Please read the information provided on this page.

You have about 10 minutes to do so.

Global climate change is seen as a serious environmental problem faced by mankind. The great majority of climate scientists expects the global average temperature to rise by $\mathbf{1 . 1}$ to 6.4 degrees Celsius until the year 2100. There is hardly any denial that mankind largely contributes to climate change by emitting greenhouse gases, especially carbon dioxide (CO2). $\mathrm{CO} 2$ originates from burning of fossil fuels like coal, oil or natural gas in industrial processes and energy production, or combustion engines of cars and lorries. $\mathrm{CO} 2$ is a global pollutant, i.e. each quantity unit of $\mathrm{CO} 2$ emitted has the same effect on the climate regardless of the location where the emission has occurred.

There are several consequences from rising temperatures. The most important consequences are stated below:

1. The sea level will rise by $\mathbf{1 8}$ to $\mathbf{5 9} \mathbf{~ c m}$ worldwide until the year 2100 . Low lying coastal regions may be threatened by floods.

2. Extreme weather events like extreme heat waves, strong rainfalls and tropical storms are likely to become more frequent.

3. Due to the shift of climate zones pathogens can spread to more northern areas than before. In southern Italy several cases of dengue fever were reported. Dengue fever is a dangerous infectious disease which usually occurs in tropical areas only.

4. Climate change does not only have negative consequences, but also positive effects. The number of heat-related deaths might increase because of more frequent periods of heat. However, due to milder winters there will be a lower number of deaths by extreme cold.

5. The consequences of climate change will vary regionally resulting in substantial consequences for agriculture. Countries in the south which today are already hot and dry will become even hotter and dryer. Especially African countries will have to expect lower crop yields. Countries in the north might profit from climate change. In Canada and the northern parts of the USA higher crop yields can be expected.

6. Briefly summarised: in Germany the following effects can be expected: Until 2050 the mean temperature will rise by 1.25 to 1.5 degrees Celsius. Winters will become milder and more humid and summers will be hotter and dryer.

Sources used (2010):

Intergovernmental Panel on Climate Change (IPCC)

German Federal Environment Agency (Umweltbundesamt)

World Health Organization (WHO) 


\section{Information on European Emissions Trading}

Please read the information provided on this page.

You will have about 10 minutes to do so.

In 2005 the European Union has implemented the emissions trading system for carbon dioxide $\left(\mathrm{CO}_{2}\right)$. Emissions trading is the central instrument of climate policy in Europe. It follows a simple principle: The European Commission, together with the member states, has determined the amount of $\mathrm{CO}_{2}$ to be emitted altogether in the respective sectors (energy production and energy intensive industries) until 2020. This total amount will be distributed to the companies by the state in the form of emission rights ("certificates"). For each quantity unit of $\mathrm{CO}_{2}$ emitted, the company has to give a certificate to the state. The certificates can be traded between companies.

For each quantity unit of $\mathrm{CO}_{2}$ emitted e.g. by a power plant, the plant operator has to prove his permission to do so in the form of a certificate. This leads to an important consequence: If the total amount of certificates is reduced, the total emissions will be lower, simply because plant operators do not possess enough emission allowances. That means if a certificate for one quantity unit is obtained from the market and is being "retired" (i.e. deleted) the total $\mathrm{CO}_{2}$ emissions are reduced by exactly this quantity amount. The opportunity to retire certificates actually exists in the framework of the EU Emissions Trading System. In Germany the German Emissions Trading Authority (DEHSt) regulates Emissions trading. The authority holds a retirement account with the account number DE230-17-1. If certificates are transferred to this account they will be withdrawn from circulation, i.e. deleted, by the end of each year.

Emissions trading has one central advantage: It guarantees that the abatement of $\mathrm{CO}_{2}$ emissions occurs where it is the cheapest option. Companies with opportunities to abate carbon in a cost-efficient way will sell their certificates on the market, whereas companies with high abatement costs can acquire certificates at a relatively low price. This trade is beneficiary for both sides and guarantees for the emission reduction target to be achieved at minimal costs.

Altogether, European energy producers and energy intensive industries were allowed to emit about two billion tons of $\mathbf{C O}_{2}$ in the year 2009. As a benchmark: global $\mathrm{CO}_{2}$ emissions per year amount for $\mathbf{2 9}$ billion tons of $\mathbf{C O}_{2}$.

Summarising, it can be stated that if the total amount of certificates in the EU Emissions Trading System is reduced, the total $\mathrm{CO}_{2}$ emissions in Europe decrease. 


\section{Purchase of $\mathrm{CO}_{2}$ Certificates}

\section{Explanation}

You are given the opportunity to buy certificates of the EU Emissions Trading System at this event. ZEW will buy the amount of certificates chosen and will retire them. Thus, you have the opportunity to contribute to the reduction of the actual $\mathrm{CO} 2$ emissions in Europe..

The purchase of the certificates will be attested by a notary public. The amount of certificates purchased will be published on the ZEW website (no names will be published).

\section{Introduction of the product " $\mathrm{CO}_{2}$ certificates".}

One unit equals 100 kilograms of $\mathrm{CO}_{2}$.

\section{Quantity you want to buy at each price.}

Please state in the table below the quantity of units (100 kg each) you are willing to buy at each price. After all participants have made their decision, we will draw by lot one of the two prices. You will then buy the quantity of units you have stated at this price.

Important note: There is no obligation to buy!

Certificates purchased have to be paid!

Please note:

The maximum expenditures for each price are $€ 25$.

\begin{tabular}{|l|l|l|l|l|}
\hline \multicolumn{5}{|c|}{ The unit is $100 \mathrm{~kg}$ of $\mathrm{CO}_{2}$} \\
\hline No. & $\begin{array}{l}\text { Price per } \\
\text { unit }\end{array}$ & $\begin{array}{l}\text { How many units do I } \\
\text { want to buy at this price? }\end{array}$ & $\begin{array}{l}\text { How many units can I } \\
\text { buy in total at this } \\
\text { price? }\end{array}$ & $\begin{array}{l}\text { Expenditures }= \\
\text { Price x Units }\end{array}$ \\
\hline 1 & $€ 2.50$ & & 10 & \\
\hline 2 & $€ 0.50$ & & 50 & \\
\hline
\end{tabular}




\section{Annex III: Alternative models}

Table 18: Econometric models of demand behavior, COLL vs. BASE

\begin{tabular}{|c|c|c|c|c|}
\hline & \multicolumn{2}{|c|}{ Two-Part Model } & \multicolumn{2}{|c|}{ Selection Two-Step Model } \\
\hline & $(1)$ & $(2)$ & (3) & (4) \\
\hline & $\begin{array}{c}\text { Decision } \\
\text { model } 3\end{array}$ & $\begin{array}{c}\text { Level } \\
\text { equation }\end{array}$ & $\begin{array}{c}\text { Level } \\
\text { equation }\end{array}$ & $\begin{array}{c}\text { Reduced level } \\
\text { equation }\end{array}$ \\
\hline & q_d & $\ln \_q_{q>0}$ & $\ln \_q_{q>0}$ & $\ln \_q_{q>0}$ \\
\hline $\ln (\mathrm{p})$ & $\begin{array}{c}-0.72^{* * * * *} \\
(0.14)\end{array}$ & $\begin{array}{c}-0.85^{* * * * 2} \\
(0.09)\end{array}$ & $\begin{array}{l}-1.09^{* 3 * 3 \times} \\
(0.21)\end{array}$ & $\begin{array}{c}-0.80^{* * * * *} \\
(0.18)\end{array}$ \\
\hline \multicolumn{5}{|l|}{ Demographics } \\
\hline Single & $\begin{array}{l}-0.90^{* * *} \\
(0.35)\end{array}$ & $\begin{array}{c}0.24 \\
(0.27)\end{array}$ & $\begin{array}{l}-0.10 \\
(0.45)\end{array}$ & \\
\hline Female & $\begin{array}{c}0.03 \\
(0.33)\end{array}$ & $\begin{array}{c}0.15 \\
(0.20)\end{array}$ & $\begin{array}{c}0.14 \\
(0.25)\end{array}$ & \\
\hline Age & $\begin{array}{l}-0.02^{*} \\
(0.01)\end{array}$ & $\begin{array}{c}0.00 \\
(0.01)\end{array}$ & $\begin{array}{l}-0.01 \\
(0.01)\end{array}$ & \\
\hline Children in household (yes/no) & $\begin{array}{l}-0.95^{* *} \\
(0.40)\end{array}$ & $\begin{array}{l}-0.58 \\
(0.37)\end{array}$ & $\begin{array}{l}-0.92^{*} \\
(0.53)\end{array}$ & \\
\hline Education (high/low) & $\begin{array}{l}-0.31 \\
(0.26)\end{array}$ & $\begin{array}{c}0.17 \\
(0.19)\end{array}$ & $\begin{array}{c}0.05 \\
(0.28)\end{array}$ & $\begin{array}{c}0.15 \\
(0.26)\end{array}$ \\
\hline Working (yes/no) & $\begin{array}{l}-0.05 \\
(0.30)\end{array}$ & $\begin{array}{l}-0.16 \\
(0.19)\end{array}$ & $\begin{array}{l}-0.15 \\
(0.24)\end{array}$ & $\begin{array}{l}-0.16 \\
(0.22)\end{array}$ \\
\hline Income ( 7 groups) & $\begin{array}{c}0.05 \\
(0.10)\end{array}$ & $\begin{array}{l}0.14^{* *} \\
(0.07)\end{array}$ & $\begin{array}{l}0.14^{*} \\
(0.08)\end{array}$ & $\begin{array}{c}0.10 \\
(0.07)\end{array}$ \\
\hline $\begin{array}{l}\text { Member in environmental } \\
\text { organization (yes/no) }\end{array}$ & $\begin{array}{c}0.43 \\
(0.41)\end{array}$ & $\begin{array}{c}0.18 \\
(0.27)\end{array}$ & $\begin{array}{c}0.32 \\
(0.34)\end{array}$ & $\begin{array}{c}0.29 \\
(0.29)\end{array}$ \\
\hline \multicolumn{5}{|l|}{ Opinions and attitudes } \\
\hline $\begin{array}{l}\text { Informational status about CC (4 } \\
\text { point scale) }\end{array}$ & $\begin{array}{c}0.12 \\
(0.21)\end{array}$ & $\begin{array}{c}0.09 \\
(0.17)\end{array}$ & $\begin{array}{c}0.12 \\
(0.20)\end{array}$ & $\begin{array}{c}0.11 \\
(0.17)\end{array}$ \\
\hline Worried about CC (5 point scale) & $\begin{array}{c}0.13 \\
(0.15)\end{array}$ & $\begin{array}{l}-0.16 \\
(0.12)\end{array}$ & $\begin{array}{l}-0.11 \\
(0.16)\end{array}$ & $\begin{array}{l}-0.12 \\
(0.13)\end{array}$ \\
\hline $\begin{array}{l}\text { CC poses a serious threat to people } \\
\text { in developing countries (yes/no) }\end{array}$ & $\begin{array}{l}0.69^{*} \\
(0.40)\end{array}$ & $\begin{array}{c}0.26 \\
(0.24)\end{array}$ & $\begin{array}{c}0.51 \\
(0.37)\end{array}$ & $\begin{array}{c}0.16 \\
(0.35)\end{array}$ \\
\hline Still need for commitment to & -0.01 & 0.30 & 0.31 & 0.35 \\
\hline tackle CC (yes/no or don't know) & $(0.42)$ & $(0.32)$ & $(0.42)$ & $(0.40)$ \\
\hline Personal behavior has influence on & -0.27 & $0.55^{* *}$ & $0.46^{*}$ & $0.56^{* *}$ \\
\hline CC (yes/no or don't know) & $(0.30)$ & $(0.23)$ & $(0.28)$ & $(0.25)$ \\
\hline \multicolumn{5}{|l|}{ Treatment indicators } \\
\hline COLL & $\begin{array}{l}0.53^{*} \\
(0.27)\end{array}$ & $\begin{array}{c}0.11 \\
(0.24)\end{array}$ & $\begin{array}{c}0.31 \\
(0.35)\end{array}$ & $\begin{array}{l}0.05 \\
(0.24)\end{array}$ \\
\hline Inverse Mills Ratio & & & $\begin{array}{c}2.71 \\
(2.36)\end{array}$ & $\begin{array}{l}-0.47 \\
(1.75)\end{array}$ \\
\hline Constant & $\begin{array}{l}4.13^{* * *} \\
(1.14) \\
\end{array}$ & $\begin{array}{l}4.61^{* * *} \\
(0.79) \\
\end{array}$ & $\begin{array}{l}4.68^{* * * *} \\
(0.89) \\
\end{array}$ & $\begin{array}{l}4.77^{* * * *} \\
(0.89) \\
\end{array}$ \\
\hline Condition Number & & 38.78 & 90.36 & 37.56 \\
\hline Adjusted $\mathrm{R}^{2}$ & & 0.459 & 0.459 & 0.420 \\
\hline $\mathrm{N}$ & 186 & 117 & 117 & 117 \\
\hline
\end{tabular}

$p<0.10,{ }^{* * *} p<0.05,{ }^{* * * *} p<0.01$, standard errors in parenthesis. CC - climate change.

Standard errors are clustered for the two-part model and bootstrapped for the two-step level equations. 
Table 19: Econometric models of demand behavior, RE Models

\begin{tabular}{|c|c|c|c|c|}
\hline & \multicolumn{2}{|c|}{ Two-Part Model } & \multicolumn{2}{|c|}{ Selection Two-Step Model } \\
\hline & $(1)$ & $(2)$ & (3) & $(4)$ \\
\hline & $\begin{array}{l}\text { Decision } \\
\text { model } 4\end{array}$ & $\begin{array}{c}\text { Level } \\
\text { equation }\end{array}$ & $\begin{array}{c}\text { Level } \\
\text { equation }\end{array}$ & $\begin{array}{c}\text { Reduced level } \\
\text { equation }\end{array}$ \\
\hline & q_d & $\ln \_q_{q}>0$ & $\ln \_q q>0$ & $\ln \_q \mathrm{q}>0$ \\
\hline $\ln (\mathrm{p})$ & $\begin{array}{l}-5.84^{* * * *} \\
(0.92)\end{array}$ & $\begin{array}{c}-0.94^{* * *} \\
(0.04)\end{array}$ & $\begin{array}{c}-0.95^{* * *} \\
(0.04)\end{array}$ & $\begin{array}{c}-0.94^{* * * *} \\
(0.04)\end{array}$ \\
\hline \multicolumn{5}{|l|}{ Demographics } \\
\hline Single & $\begin{array}{l}-7.63^{* *} \\
(3.46)\end{array}$ & $\begin{array}{c}0.05 \\
(0.23)\end{array}$ & $\begin{array}{c}0.03 \\
(0.23)\end{array}$ & \\
\hline Female & $\begin{array}{l}-0.37 \\
(2.55)\end{array}$ & $\begin{array}{c}0.08 \\
(0.17)\end{array}$ & $\begin{array}{c}0.08 \\
(0.17)\end{array}$ & \\
\hline Age & $\begin{array}{l}-0.21^{* *} \\
(0.11)\end{array}$ & $\begin{array}{l}-0.00 \\
(0.01)\end{array}$ & $\begin{array}{l}-0.00 \\
(0.01)\end{array}$ & \\
\hline Children in household (yes/no) & $\begin{array}{c}-10.29^{* *} \\
(4.01)\end{array}$ & $\begin{array}{l}-0.65^{*} \\
(0.34)\end{array}$ & $\begin{array}{l}-0.68^{* * *} \\
(0.35)\end{array}$ & \\
\hline Education (high/low) & $\begin{array}{c}0.27 \\
(1.99)\end{array}$ & $\begin{array}{c}0.16 \\
(0.17)\end{array}$ & $\begin{array}{l}0.15 \\
(0.17)\end{array}$ & $\begin{array}{c}0.10 \\
(0.17)\end{array}$ \\
\hline Working (yes/no) & $\begin{array}{l}2.48 \\
(2.40)\end{array}$ & $\begin{array}{l}-0.14 \\
(0.18)\end{array}$ & $\begin{array}{l}-0.12 \\
(0.18)\end{array}$ & $\begin{array}{l}-0.07 \\
(0.17)\end{array}$ \\
\hline Income ( 7 groups) & $\begin{array}{c}0.70 \\
(0.94)\end{array}$ & $\begin{array}{l}0.12^{*} \\
(0.07)\end{array}$ & $\begin{array}{l}0.12^{*} \\
(0.07)\end{array}$ & $\begin{array}{c}0.09 \\
(0.06)\end{array}$ \\
\hline $\begin{array}{l}\text { Member in environmental } \\
\text { organization (yes/no) }\end{array}$ & $\begin{array}{l}-1.31 \\
(3.69)\end{array}$ & $\begin{array}{c}0.21 \\
(0.25)\end{array}$ & $\begin{array}{c}0.21 \\
(0.25)\end{array}$ & $\begin{array}{c}0.31 \\
(0.24)\end{array}$ \\
\hline \multicolumn{5}{|l|}{ Opinions and attitudes } \\
\hline $\begin{array}{l}\text { Informational status about CC (4 } \\
\text { point scale) }\end{array}$ & $\begin{array}{l}3.75^{*} \\
(1.95)\end{array}$ & $\begin{array}{c}0.08 \\
(0.15)\end{array}$ & $\begin{array}{c}0.09 \\
(0.15)\end{array}$ & $\begin{array}{c}0.12 \\
(0.13)\end{array}$ \\
\hline Worried about CC (5 point scale) & $\begin{array}{l}1.90^{*} \\
(1.09)\end{array}$ & $\begin{array}{l}-0.05 \\
(0.08)\end{array}$ & $\begin{array}{l}-0.05 \\
(0.08)\end{array}$ & $\begin{array}{l}-0.04 \\
(0.08)\end{array}$ \\
\hline $\begin{array}{l}\text { CC poses a serious threat to people } \\
\text { in developing countries (yes/no) }\end{array}$ & $\begin{array}{l}5.57^{*} \\
(3.05)\end{array}$ & $\begin{array}{c}0.14 \\
(0.23)\end{array}$ & $\begin{array}{c}0.17 \\
(0.23)\end{array}$ & $\begin{array}{c}0.13 \\
(0.23)\end{array}$ \\
\hline Still need for commitment to & 1.70 & 0.22 & 0.22 & 0.24 \\
\hline tackle CC (yes/no or don't know) & $(3.34)$ & $(0.25)$ & $(0.25)$ & $(0.27)$ \\
\hline Personal behavior has influence on & -0.66 & $0.51^{* *}$ & $0.51^{* *}$ & $0.54^{* *}$ \\
\hline CC (yes/no or don't know) & $(2.50)$ & $(0.21)$ & $(0.21)$ & $(0.22)$ \\
\hline \multicolumn{5}{|l|}{ Treatment indicators } \\
\hline INFO & $\begin{array}{l}1.61 \\
(2.67)\end{array}$ & $\begin{array}{c}0.00 \\
(0.21)\end{array}$ & $\begin{array}{c}0.01 \\
(0.21)\end{array}$ & $\begin{array}{c}0.01 \\
(0.20)\end{array}$ \\
\hline COLL & $\begin{array}{l}6.91^{* *} \\
(2.70)\end{array}$ & $\begin{array}{c}0.25 \\
(0.25)\end{array}$ & $\begin{array}{c}0.27 \\
(0.25)\end{array}$ & $\begin{array}{c}0.18 \\
(0.23)\end{array}$ \\
\hline Inverse Mills Ratio & & & $\begin{array}{c}0.02 \\
(0.02)\end{array}$ & $\begin{array}{c}0.01 \\
(0.02)\end{array}$ \\
\hline Constant & $\begin{array}{c}20.07^{* *} \\
(9.21) \\
\end{array}$ & $\begin{array}{l}5.02^{* * *} \\
(0.59)\end{array}$ & $\begin{array}{l}5.05^{* * * *} \\
(0.59) \\
\end{array}$ & $\begin{array}{l}4.91^{* * * *} \\
(0.56) \\
\end{array}$ \\
\hline $\mathrm{N}$ & 270 & 166 & 166 & 166 \\
\hline
\end{tabular}




\section{Annex IV: Model fit}

Figure 5 shows the fitted probabilities of model 3 across the different treatments. The mean fitted probabilities are close to the observed probabilities. The worst predictions are made at the price of $250 €$ cents in BASE and COLL. Across treatments there seems to be a reasonable model fit in all treatments, although in BASE the fitted portion of buyers tends to be higher than the observed portion and in COLL the fitted proportion tends to be lower than the observed proportion who bought permits.

\section{Figure5: Observed vs. fitted probabilities to purchase - model 3}

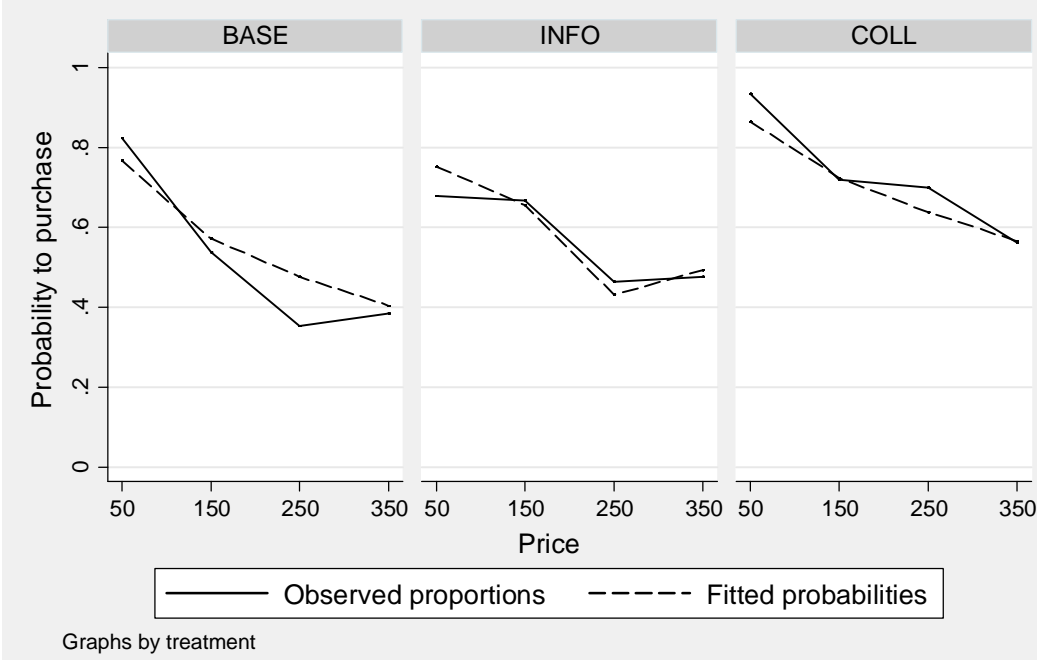

Figure 6 shows that the model fit of the RE model is worse than the clustered errors structure. 
Figure 6: Observed vs. fitted probabilities to purchase - model 4

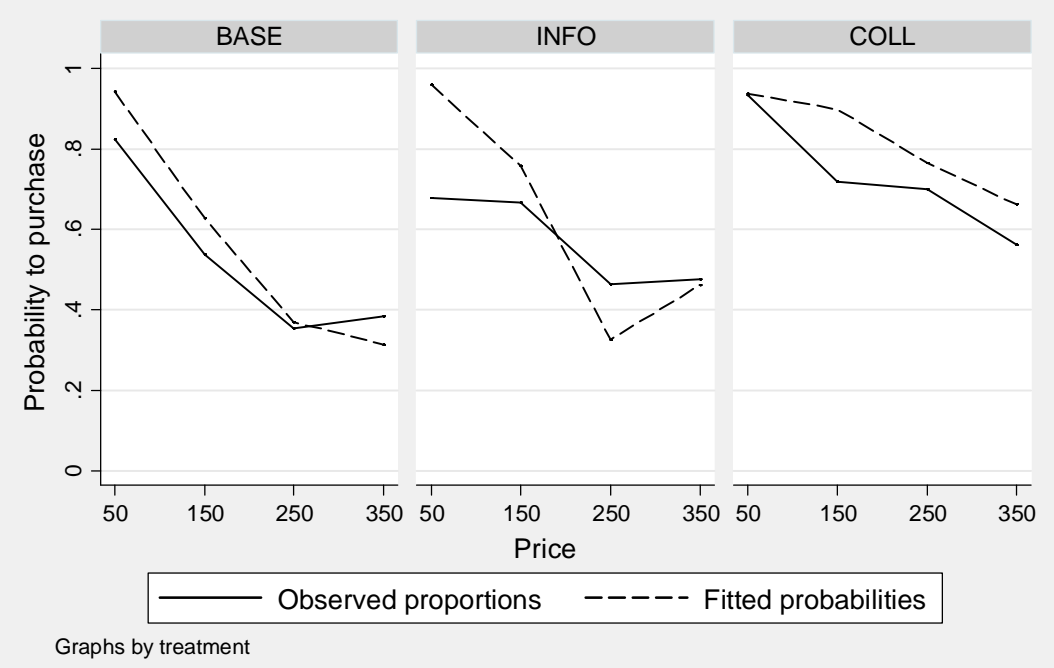

